OPEN ACCESS

Edited by:

Peter Stief,

University of Southern Denmark,

Denmark

Reviewed by:

Markus Huettel,

Florida State University, USA

Charles Schutte,

Max Planck Institute for Marine

Microbiology, Germany

*Correspondence:

Emilio Garcia-Robledo

emilio.garcia@bios.au.dk

Specialty section:

This article was submitted to

Aquatic Microbiology,

a section of the journal

Frontiers in Microbiology

Received: 25 January 2016 Accepted: 05 May 2016

Published: 26 May 2016

Citation:

Garcia-Robledo E, Bohorquez J,

Corzo A, Jimenez-Arias $J L$ and

Papaspyrou S (2016) Dynamics of

Inorganic Nutrients in Intertidal

Sediments: Porewater, Exchangeable, and Intracellular Pools.

Front. Microbiol. 7:761.

doi: 10.3389/fmicb.2016.00761

\section{Dynamics of Inorganic Nutrients in Intertidal Sediments: Porewater, Exchangeable, and Intracellular Pools}

\author{
Emilio Garcia-Robledo ${ }^{1,2 *}$, Julio Bohorquez ${ }^{2}$, Alfonso Corzo ${ }^{2}$, Juan L. Jimenez-Arias ${ }^{2}$ and \\ Sokratis Papaspyrou ${ }^{3}$
}

${ }^{1}$ Microbiology Section, Department of Biosciences, Aarhus University, Aarhus, Denmark, ${ }^{2}$ Departamento de Biología, Facultad de Ciencias del Mar y Ambientales, Universidad de Cádiz, Puerto Real, Spain, ${ }^{3}$ Laboratorio de Microbiología, Departamento de Biomedicina, Biotecnología y Salud Pública, Facultad de Ciencias, Universidad de Cádiz, Puerto Real, Spain

The study of inorganic nutrients dynamics in shallow sediments usually focuses on two main pools: porewater (PW) nutrients and exchangeable (EX) ammonium and phosphate. Recently, it has been found that microphytobenthos (MPB) and other microorganisms can accumulate large amounts of nutrients intracellularly (IC), highlighting the biogeochemical importance of this nutrient pool. Storing nutrients could support the growth of autotrophs when nutrients are not available, and could also provide alternative electron acceptors for dissimilatory processes such as nitrate reduction. Here, we studied the magnitude and relative importance of these three nutrient pools (PW, IC, and EX) and their relation to chlorophylls (used as a proxy for MPB abundance) and organic matter (OM) contents in an intertidal mudflat of Cadiz Bay (Spain). MPB was localized in the first $4 \mathrm{~mm}$ of the sediment and showed a clear seasonal pattern; highest chlorophylls content was found during autumn and lowest during spring-summer. The temporal and spatial distribution of nutrients pools and MPB were largely correlated. Ammonium was higher in the IC and EX fractions, representing on average 59 and $37 \%$ of the total ammonium pool, respectively. Similarly, phosphate in the IC and EX fractions accounted on average for 40 and $31 \%$ of the total phosphate pool, respectively. Nitrate in the PW was low, suggesting low nitrification activity and rapid consumption. Nitrate accumulated in the IC pool during periods of moderate MPB abundance, being up to $66 \%$ of the total nitrate pool, whereas it decreased when chlorophyll concentration peaked likely due to a high nitrogen demand. EX-Nitrate accounted for the largest fraction of total sediment nitrate, $66 \%$ on average. The distribution of EX-Nitrate was significantly correlated with chlorophyll and $\mathrm{OM}$, which probably indicates a relation of this pool to an increased availability of sites for ionic adsorption. This EX-Nitrate pool could represent an alternative nitrate source with significant concentrations available to the microbial community, deeper in the sediment below the oxic layer.

Keywords: microphytobenthos, intracellular nutrients, exchangeable nutrients, porewater nutrients, ammonium, nitrate, phosphate, intertidal sediments 


\section{INTRODUCTION}

Sediment inorganic nutrients are a key biogeochemical component of aquatic ecosystems. Studying the seasonal and spatial changes in nutrient fluxes and water column concentrations in aquatic systems allow us to explain the ecosystem's productivity. However, interpretation of nutrient data is often difficult due to the complex interactions and overall dynamics of the various sediment nutrient pools. Mineralization of organic matter in the upper layers of the sediment, particularly in shallow environments, releases inorganic nutrients to the pore water (PW) which are exchanged with the water column by diffusive and advective transport processes. Alternatively, nutrients in the pore water can be adsorbed to different degrees to either organic compounds or clay particles in the sediment (Mackin and Aller, 1984; Coelho et al., 2004). The adsorbed fraction is typically referred to as the exchangeable nutrient fraction (EX). In addition, nutrients in the pore water are consumed by sediment microalgae and prokaryotes for assimilatory or dissimilatory purposes.

During the last decade, the capacity of some components of the microbial benthic community to store large concentrations of nutrients intracellularly (intracellular fraction, IC) has been emphasized (Kamp et al., 2015). In a previous study, we established a clear relation between the freeze-lysable inorganic nutrient pool (FLIN) and microphytobenthos (MPB) abundance, which suggested that benthic microalgae are able to accumulate nitrate, ammonium, and phosphate intracellularly (GarcíaRobledo et al., 2010). Kamp et al. (2011), using axenic cultures, demonstrated that benthic diatoms can accumulate nitrate intracellularly, being able to use it to survive during dark and anoxic periods. During an annual study, Stief et al. (2013) showed that benthic diatoms in intertidal sediments of the Wadden Sea also accumulate nitrate. More recently, Yamaguchi et al. (2015) demonstrated that microalgae from intertidal sediments of Ariake Bay (Japan) accumulate both organic and inorganic phosphorus intracellularly.

The PW, EX, and IC nutrient pools are subject most likely to different biogeochemical and ecological controls. Therefore, fractionation of inorganic nutrients in the various sediment pools needs to be addressed both conceptually and methodologically. This will allow identifying the relevant nutrient fractions that should be quantified in aquatic sediments to answer specific biogeochemical problems. The seasonal variations of environmental variables and nutrient supplies in Cadiz Bay are expected to determine the variations of MPB inhabiting the intertidal areas. In a previous study based on only two samplings (summer/winter), García-Robledo et al. (2010) suggested that the magnitude and fractionation of the different nutrients in the PW and IC fractions is likely related to the MPB abundance and activity. For Wadden Sea sediments, Stief et al. (2013) also suggested a link between nitrate pools and MPB variations over a 12 month period; however, no information was provided about other relevant inorganic nutrients such as ammonium or phosphate. Thus, the relative importance of these nutrient pools and their seasonal dynamics remain largely unknown. In addition, the other major nutrient pool in marine sediment, the exchangeable fraction, has not been studied simultaneously with the PW and IC pools before.

The aim of this study was to understand the ecological and biogeochemical importance of each of the three nutrient pools, PW, EX, and IC. We hypothesize that these pools must be functionally linked to the microbial community, particularly to $\mathrm{MPB}$, and therefore will exhibit spatial and temporal variability related to that of biological and abiotic variables in the water column and the sediment. To test this, here we analyze the relationships between chlorophyll content, used as a proxy for $\mathrm{MPB}$ abundance, and inorganic nutrients $\left(\mathrm{NH}_{4}^{+}, \mathrm{NO}_{3}^{-}\right.$, $\mathrm{PO}_{4}^{3-}$, and $\mathrm{SiO}_{4}^{4-}$ ) changes in the three sediment pools. These relationships were evaluated using data obtained from an intertidal sediment area of Cadiz Bay (Spain) with depth (upper 1 $\mathrm{cm}$ ) during a period of 18 months. Although, intertidal sediments are exposed to periodical immersion and emersion periods which have been shown to affect the inorganic nutrient dynamics (Rocha and Cabral, 1998; Rocha, 1999; Hou et al., 2005), our study was not focused on the short-term effects produced by the tidal cycle but rather on seasonal changes. Thus, samplings were carried out always during emersion periods in order to simplify the sampling strategy. In addition, in the present study, we focused on the pools that we considered the most readily available for the microorganisms or in direct physicochemical equilibrium with the pore water. For the first time the PW, IC, and EX nutrient pools were extracted using a sequential procedure, allowing us to compare directly the different ammonium, nitrate, phosphate nutrient pools and to determine their relationship with the seasonal MPB cycle. In addition, as a first approach to understand the ecological and biogeochemical importance of each of these nutrient pools, we explore the relationships of their spatial and seasonal variability with biological and abiotic variables in the water column and the sediment.

\section{MATERIALS AND METHODS}

\section{Sampling Site and Collection of Samples}

Sediment samples were collected monthly at an unvegetated intertidal site in Trocadero Island $\left(\begin{array}{lllll}36^{\circ} & 31^{\prime} & 09^{\prime \prime} & \mathrm{N}, 6^{\circ} & 12^{\prime}\end{array}\right.$ $01^{\prime \prime}$ W; inner Cadiz Bay, Spain) from January 2008 to June 2009. Sediment was silty mud and no macroalgae or seagrass detritus were observed at the surface of the sampled sediment. A detailed description of the sampling point can be found in Papaspyrou et al. (2013). From December 2008 to February 2009, when green macroalgae (tubular Ulva sp.) covered large patches of the sediment surface, care was taken to collect sediment samples in non-covered areas. Sediment cores were collected using cutoff syringes (i.d. $1.6 \mathrm{~cm}, n=7$ ) from three random sediment plots $\left(1 \times 1 \mathrm{~m}^{2}\right)$ separated $10-15 \mathrm{~m}$ between them (21 cores in total). Sediment collection was always performed during low tide shortly after the sediment got exposed. We selected cores of small diameter to facilitate subsequent sediment slicing at millimeter scale. Another two sediment cores with a larger diameter (plexiglas core liners, i.d. $5.4 \mathrm{~cm}$ ) were collected in each one of the three random plots for microsensor measurements ( 6 cores in total). Water column samples $(20 \mathrm{~mL}, n=3)$ were collected from the adjacent subtidal area. All cores and water 
samples were maintained on ice and transported immediately to the laboratory. Water samples were filtered immediately after arriving to the laboratory and stored frozen $\left(-20^{\circ} \mathrm{C}\right)$ until later analysis. Nutrient concentrations $\left(\mathrm{NH}_{4}^{+}, \mathrm{NO}_{2}^{-}, \mathrm{NO}_{3}^{-}, \mathrm{PO}_{4}^{3-}\right.$, and $\mathrm{SiO}_{4}^{4-}$ ) were measured as described below.

\section{Microsensor Measurements}

After arriving to the laboratory, the large sediment cores were maintained in an aquarium illuminated with halogen lamps at $800 \mu \mathrm{E} \mathrm{m}^{-2} \mathrm{~s}^{-1}$ (average annual PPF value) under a $12 \mathrm{~h}$ light:12 $\mathrm{h}$ dark photoperiod. The aquarium was filled with seawater collected in situ. In order to measure steady state profiles, sediment cores were maintained overnight in the aquarium at room temperature $\left(20-22^{\circ} \mathrm{C}\right)$ and microsensor measurements were performed the following day. Oxygen profiles $(n=3-4$ per core) were measured in light and in darkness in each of the six sediment cores using $\mathrm{O}_{2}$ microelectrodes $(25 \mu \mathrm{m}$ tip size, UNISENSE A/S, Denmark). Light conditions were maintained for at least $2 \mathrm{~h}$ prior to measuring the profiles. Potential net primary production $(\mathrm{pPn})$ and dark respiration $(\mathrm{pRd})$ were calculated from the $\mathrm{O}_{2}$ gradient at the diffusive boundary layer of the light and dark profiles, respectively (Revsbech and Jorgensen, 1986; Kühl et al., 1996). Potential Net Daily Production (NDP), expressed as daily net rates $\left(\mathrm{mmol} \mathrm{O}_{2} \mathrm{~m}^{-2} \mathrm{~d}^{-1}\right)$, was calculated as the sum of the product of $\mathrm{pPn}$ and $\mathrm{pRd}$ rates multiplied by the corresponding number of hours in day or night (natural photoperiod), respectively, each month.

\section{Sequential Nutrient Pools Extraction}

Once in the laboratory, the small diameter sediment cores (i.d. 1.6 $\mathrm{cm}$ ) were sliced using a razor blade and a caliper into 1 millimeter sections down to $10 \mathrm{~mm}$ depth by slowly pushing up the syringe piston. This fine sectioning was possible due to the consolidated nature of the sediment found at our sampling point and the small diameter of the cores. Slices of four cores from the same depth and plot were pooled to obtain a sufficiently large amount of sample and homogenized.

Nutrient pools were then extracted sequentially from the sediment using the following sequence:

- Pore water (PW) extraction: pore water was extracted from the sediment by centrifugation at $8600 \times \mathrm{g}$ for $20 \mathrm{~min}$ at $4^{\circ} \mathrm{C}$. All the supernatant was extracted recording the volume obtained $(0.15-0.6 \mathrm{~mL})$ and preserved at $-20^{\circ} \mathrm{C}$.

- Intracellular (IC) or Freeze-Lysable Inorganic Nutrient (FLIN) extraction: in order to break the MPB cells and release their intracellular content, sediment was freeze-thawed three times. Freezing was achieved at $-80^{\circ} \mathrm{C}$ and thawing at room temperature. Freeze-thawed sediment was then resuspended in $4 \mathrm{~mL}$ of artificial sea water (40 PSU), centrifuged at $8600 \times \mathrm{g}$ for $20 \mathrm{~min}$ at $4^{\circ} \mathrm{C}$, and the supernatant collected and preserved at $-20^{\circ} \mathrm{C}$.

- KCl-Exchangeable fraction (EX): Immediately after the extraction of IC nutrients, $2 \mathrm{~mL}$ of a $2 \mathrm{M} \mathrm{KCl}$ solution were added to the samples. Sediment was resuspended and incubated at $4^{\circ} \mathrm{C}$ for $30 \mathrm{~min}$ (Holmboe and Kristensen, 2002) and the supernatant extracted and preserved at $-20^{\circ} \mathrm{C}$.
Nutrient samples were diluted initially to a total volume of 4 $\mathrm{mL}$ with artificial sea water (for PW and IC samples) or Milli$\mathrm{Q}$ water (for EX samples). Concentrations of $\mathrm{NH}_{4}^{+}, \mathrm{NO}_{2}^{-}, \mathrm{NO}_{3}^{-}$, $\mathrm{PO}_{4}^{3-}$, and $\mathrm{SiO}_{4}^{4-}$ were measured on a Technicon Autoanalyzer (TRAACS-800) following standard protocols (Grasshoff et al., 1983). Further dilutions were done when concentrations exceeded the calibration curve range.

\section{Photosynthetic Pigments and Organic Matter Measurements}

Immediately after EX extraction, pigments were extracted from the same sediment samples. Chlorophylls (Chl) were extracted in $100 \%$ methanol buffered with $\mathrm{MgCO}_{3}$ overnight at $4^{\circ} \mathrm{C}$ in darkness (Thompson et al., 1999). Extracts were centrifuged at $2200 \times \mathrm{g}$ for $10 \mathrm{~min}$ and absorbance was measured using a spectrophotometer (Unicam UV/Vis UV2 ${ }^{\circledR}$ ). Chl $a$ and $c$ were estimated after Ritchie (2008). It is likely that the nutrients extraction procedure may have degraded partly the chlorophylls in the samples and chlorophyll values here may underestimate in situ values. Sediment samples were then dried at $60^{\circ} \mathrm{C}$ for 24 $\mathrm{h}$ to determine the dry weight $(\mathrm{g} \mathrm{dw})$ and porosity in order to normalize the measured variables.

The remaining sediment cores ( $n=3$, per station) were sliced in $2 \mathrm{~mm}$ sections. Samples were dried at $60^{\circ} \mathrm{C}$ for $24 \mathrm{~h}$ and organic matter content (OM) was estimated as loss on ignition (Heiri et al., 2001).

\section{Calculations of Nutrient Pools Content}

Nutrient concentrations ( $\mu \mathrm{mol} \mathrm{L}^{-1}$, equivalent to $\mathrm{nmol} \mathrm{mL} \mathrm{m}^{-1}$ ) measured in the extracts were converted to nutrient content in the different pools $\left(\mathrm{nmol} \mathrm{cm}^{-3}\right.$ ). The contribution of the residual water remaining in the sediment after each supernatant extraction step was also taken into account in the calculations of the nutrient pools using the following equations:

$$
\begin{aligned}
& P W\left(\mathrm{nmol} \mathrm{cm}^{-3}\right)=\left[\frac{C_{P W} \times V_{T}}{W}\right] \times \rho_{D} \\
& I C(\mathrm{nmol} \mathrm{cm}-3)= \\
& {\left[\frac{C_{I C} \times\left(V_{A S W}+V_{R P W}\right)-\left(C_{P W} \times V_{R P W}\right)}{W}\right] \times \rho_{D}} \\
& E X\left(n m o l \mathrm{~cm}^{-3}\right)= \\
& {\left[\frac{C_{E X} \times\left(V_{K C l}+V_{R I C}\right)-\left(C_{I C} \times V_{R I C}\right)}{W}\right] \times \rho_{D}}
\end{aligned}
$$

where, $C_{P W}$ is the nutrient concentration in the porewater (nmol $\left.\mathrm{mL}^{-1}\right) ; C_{I C}$ is the nutrient concentration in the IC extraction $\left(\mathrm{nmol} \mathrm{mL} \mathrm{m}^{-1}\right) ; C_{E X}$ is the nutrient concentration in the $\mathrm{KCl}$ extraction $\left(\mathrm{nmol} \mathrm{mL} \mathrm{m}^{-1}\right) ; V_{T}$ is the total water volume of the sediment sample (fresh-dry weight) $(\mathrm{mL}) ; V_{A S W}$ and $V_{K C l}$ are the volume of artificial sea water added for the IC and $\mathrm{KCl}$ extractions ( 4 and $2 \mathrm{~mL}$, respectively); $V_{R P W}$ and $V_{R I C}$ are the residual water volume remaining after the extractions of pore water and IC $(\mathrm{mL}) ; W$ is the dry weight of the sediment sample $(g d w) ; \rho_{D}$ is the dry density of the fresh sediment $\left(0.66 \mathrm{~g} \mathrm{dw} \mathrm{cm}^{-3}\right)$.

Considering standard limits of detection of $0.1 \mu \mathrm{M}$ for $\mathrm{PO}_{4}^{3-}$ and $0.5 \mu \mathrm{M}$ for $\mathrm{NH}_{4}^{+}$and $\mathrm{NO}_{3}^{-}$for the analysis of the diluted 
PW and the IC and EX extracts and an average sample weight of $0.5 \mathrm{~g} \mathrm{dw}$, the detection limits for the pools was $0.5 \mathrm{nmol} \mathrm{cm}^{-3}$ for $\mathrm{PO}_{4}^{3-}$ and $2.6 \mathrm{nmol} \mathrm{cm}^{-3}$ for $\mathrm{NH}_{4}^{+}$and $\mathrm{NO}_{3}^{-}$.

\section{Statistical Analysis}

The relationship between the different sediment fractions of $\mathrm{PO}_{4}^{3-}, \mathrm{NH}_{4}^{+}$, and $\mathrm{NO}_{3}^{-}$with their corresponding water column concentrations, MPB biomass, OM content, NDP, and climatological variables (i.e., air temperature, rainfall, and irradiance) were initially analyzed by Spearman correlation analysis to produce two correlation matrices. Monthly averages (average of the 3 profiles per month) of each nutrient pool, photosynthetic pigments, and OM profiles $(n=17$ months $\times 10$ depths $=170$ ) were used to calculate correlations between the variables including both spatial (vertical) and temporal variability. In order to establish correlations with other environmental (climatological and water column nutrients) and biological (NDP and Chl $a$ and $c$ ) variables, the upper $4 \mathrm{~mm}$ of the $\mathrm{OM}$ and nutrients pools were integrated. Variability was then reduced to temporal changes and thus, Spearman correlations $(n=17$ months $\times 3$ plots $=51)$ could be calculated between the nutrient pools and the rest of the variables.

\section{RESULTS}

\section{Porewater and Water Column Nutrients}

Porewater nutrient (PW) contents showed pronounced spatial and seasonal changes for all the analyzed nutrients (Figures 1, 2). In general, nutrient contents were low and increased during autumn, peaking at the sediment surface in December 2008 with values of 89.4, 9.2, and $28.4 \mathrm{nmol} \mathrm{cm} \mathrm{cm}^{-3}$ for $\mathrm{PW}$ ammonium $\left(\mathrm{PW}-\mathrm{NH}_{4}^{+}\right)$, phosphate $\left(\mathrm{PW}-\mathrm{PO}_{4}^{3-}\right)$, and nitrate $\left(\mathrm{PW}-\mathrm{NO}_{3}^{-}\right)$, respectively. Nutrients content integrated in the first $4 \mathrm{~mm}$ showed the same pattern, with high values during autumn and very low values during spring-summer months (Figure 3B). The content of $\mathrm{PW}-\mathrm{SiO}_{4}^{4-}$ in the first $4 \mathrm{~mm}$ of the sediment increased after July 2008, from relatively low values of $1 \mathrm{nmol} \mathrm{cm}^{-3}$ to values higher than $10 \mathrm{nmol} \mathrm{cm}{ }^{-3}$, peaking in January 2009 (Figure 3B).

Nutrients in the water column varied throughout the sampled period (Figure 3A). Silicate was the most abundant nutrient with a maximum concentration of $18.0 \mu \mathrm{M}$ and a mean concentration of $8.8 \mu \mathrm{M}$. Nitrate was the second most abundant nutrient with maximum concentration of $6.2 \mu \mathrm{M}$ during January 2009. Nitrate concentrations were almost zero during the first half of 2008 and increased after August 2008 to values around $3.0 \mu \mathrm{M}$, decreasing again in June 2009. Phosphate and ammonium concentrations were generally low, remaining below $1 \mu \mathrm{M}$. Higher ammonium concentrations were measured during February $2008(2.1 \mu \mathrm{M})$ and from July to October $2008(1.3-1.7 \mu \mathrm{M})$. Phosphate also increased during the same periods, reaching values of $0.9 \mu \mathrm{M}$ in February 2008 and $2.2 \mu \mathrm{M}$ in November 2008.

The contribution of $\mathrm{PW}-\mathrm{PO}_{4}^{3-}, \mathrm{PW}-\mathrm{NH}_{4}^{+}$, and $\mathrm{PW}-\mathrm{NO}_{3}^{-}$to the total corresponding nutrient content in the sediment varied considerably, both with depth within the sediment and along the seasonal cycle (Figure 4). $\mathrm{PW}-\mathrm{NH}_{4}^{+}$accounted for only $4.1 \pm$ $3.1 \%$ (mean $\pm \mathrm{SD}$ ) of the total ammonium content, being around
$3 \%$ throughout the studied period and increasing to mean values of $8 \%$ in spring-summer 2009. $\mathrm{PW}-\mathrm{PO}_{4}^{3-}$ comprised on average $29 \pm 24 \%$ of the total. It increased generally with sediment depth and was more important during autumn and winter (September 2008 to February 2009) when it was above $60 \%$. $\mathrm{PW}-\mathrm{NO}_{3}^{-}$ contribution to sediment nitrate was similar to $\mathrm{PW}-\mathrm{PO}_{4}^{3-}$; its average contribution was $21 \pm 14 \%$ (mean $\pm \mathrm{SD}$ ) being highest during winter, when it accounted for up to $50 \%$ of the total sediment nitrate.

\section{Intracellular Nutrients}

The Intracellular (IC) pool was highly variable both spatially and temporally. The three main nutrients analyzed ( $\mathrm{IC}^{-} \mathrm{PO}_{4}^{3-}$, IC- $\mathrm{NH}_{4}^{+}$, and $\mathrm{IC}-\mathrm{NO}_{3}^{-}$) showed a common profile; IC contents peaked at the sediment surface, decreasing exponentially with depth to relatively constant values below $4-5 \mathrm{~mm}$ depth (Figures 1, 2). IC- $\mathrm{NH}_{4}^{+}$and $\mathrm{IC}-\mathrm{PO}_{4}^{3-}$ showed the highest concentrations at the sediment surface from November 2008 to January 2009 (6934-7672 and $117.4-97.5 \mathrm{nmol} \mathrm{cm}^{-3}$ for IC- $\mathrm{NH}_{4}^{+}$ and $\mathrm{IC}^{-} \mathrm{PO}_{4}^{3-}$, respectively). It is noteworthy that both nutrients showed two peak values, one just before (November 2008) and one after (January 2009) the Chl $a$ maximum (Figures 1, 3). In contrast, $\mathrm{IC}^{-\mathrm{NO}_{3}^{-}}$content was minimal during the $\mathrm{Chl} a$ peak, and was highest before and after $\mathrm{Chl} a$ content started to increase (i.e., in February 2008, September 2008, and February 2009). During these months, the $0-4 \mathrm{~mm}$ integrated $\mathrm{IC}-\mathrm{NO}_{3}^{-}$content varied from 1.6 to $6.8 \mathrm{nmol} \mathrm{cm}^{-2}$, whereas it remained at values below $1 \mathrm{nmol} \mathrm{cm}^{-2}$ during the rest of the year (Figure 3).

IC- $\mathrm{NH}_{4}^{+}$and IC- $\mathrm{PO}_{4}^{3-}$ were the main sediment nutrient pool, contributing on average $59 \pm 15 \%$ and $40 \pm 24 \%$, respectively (Figure 4). These pools were dominant close to the sediment surface, with their contribution decreasing progressively with depth. The IC- $\mathrm{NH}_{4}^{+}$pool showed a clear seasonal pattern, with higher contribution during autumn-winter months and lower in spring-summer. In contrast, little nitrate was found in the IC fraction in the sediments of Cádiz Bay $(9 \pm 15 \%)$. IC- $\mathrm{NO}_{3}^{-}$ was relatively important only in the 2008 winter season, with contributions higher than $40 \%$ on occasions.

\section{Exchangeable Nutrients}

Exchangeable (EX) fractions of ammonium $\left(\mathrm{EX}^{-} \mathrm{NH}_{4}^{+}\right.$) and phosphate $\left(\mathrm{EX}-\mathrm{PO}_{4}^{3-}\right)$ showed, to some extent, a similar pattern to that of the IC ones. Highest values were observed within the upper two millimeters of the sediment (1324-1365 nmol $\mathrm{cm}^{-3}$ for $\mathrm{EX}-\mathrm{NH}_{4}^{+}$and $40.8-43.3 \mathrm{nmol} \mathrm{cm}{ }^{-3}$ for $\mathrm{EX}-\mathrm{PO}_{4}^{3-}$ ) in December 2008 and January 2009 (Figure 1), whereas values were low below 2-3 mm depth for $\mathrm{EX}^{-\mathrm{PO}_{4}^{3-}}$ and 5-6 $\mathrm{mm}$ for $\mathrm{EX}-\mathrm{NH}_{4}^{+}$. During the rest of the year, values were relatively low with no clear vertical structure. The exchangeable nitrate fraction $\left(\mathrm{EX}-\mathrm{NO}_{3}^{-}\right)$also showed maximum values at the sediment surface $\left(46.5 \pm 6.4 \mathrm{nmol} \mathrm{cm} \mathrm{cm}^{-3}\right)$ and lower values at deeper depths (Figures 1, 2). Seasonal variations of $\mathrm{EX}^{-\mathrm{NO}_{3}^{-}}$were less pronounced when compared to the other nutrients; highest contents were measured in November 2008, February 2009, and June 2009.

EX- $\mathrm{PO}_{4}^{3-}$ represented a similar percentage of total $\mathrm{PO}_{4}^{3-}$ as $\mathrm{IC}-\mathrm{PO}_{4}^{3-}$, making up $31 \pm 15 \%$ of the total $\mathrm{PO}_{4}^{3-}$ pool 


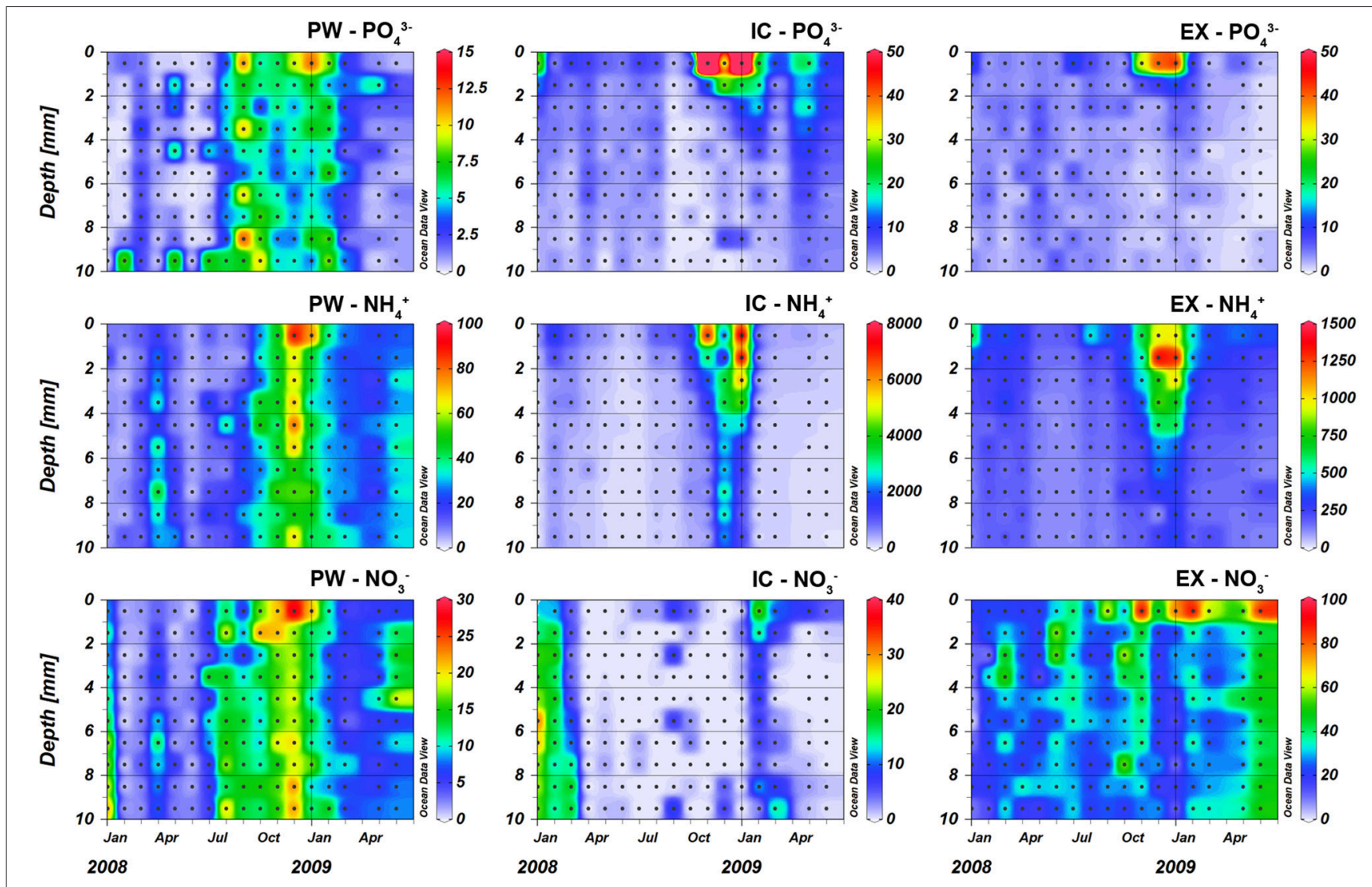

FIGURE 1 | Nutrient content $\left(\mathrm{nmol} \mathrm{cm}^{-3}\right)$ in the porewater (PW), intracellular (IC), and $\mathrm{KCl}$ exchangeable (EX) fractions at the sampling station on Trocadero Island, Bay of Cádiz from January 2008 to June 2009. Notice the different scales of each graph. Data are mean of 3 sediment plots.
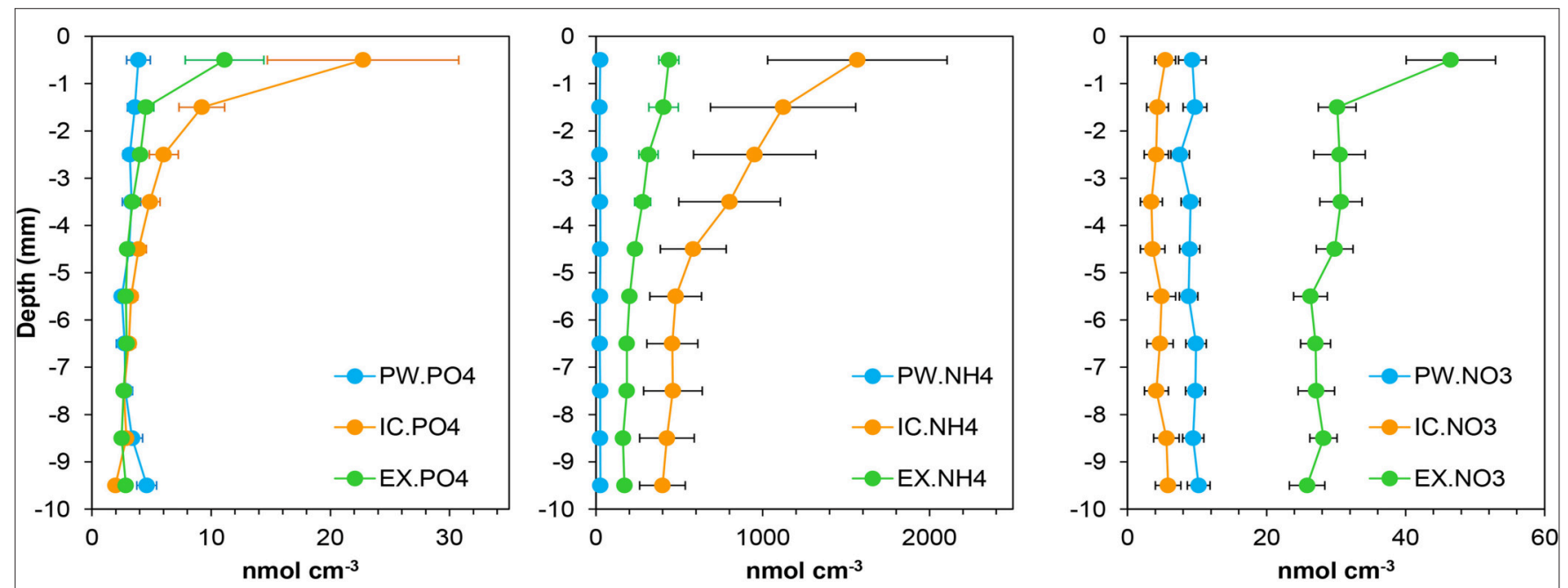

FIGURE 2 | Mean profiles of the nutrient pools content in the porewater (PW), intracellular (IC), and $\mathrm{KCl}$ exchangeable (EX) fractions at the sampling station on Trocadero Island, Bay of Cádiz. Data are mean of 17 months \pm SE (from January 2008 to June 2009). 

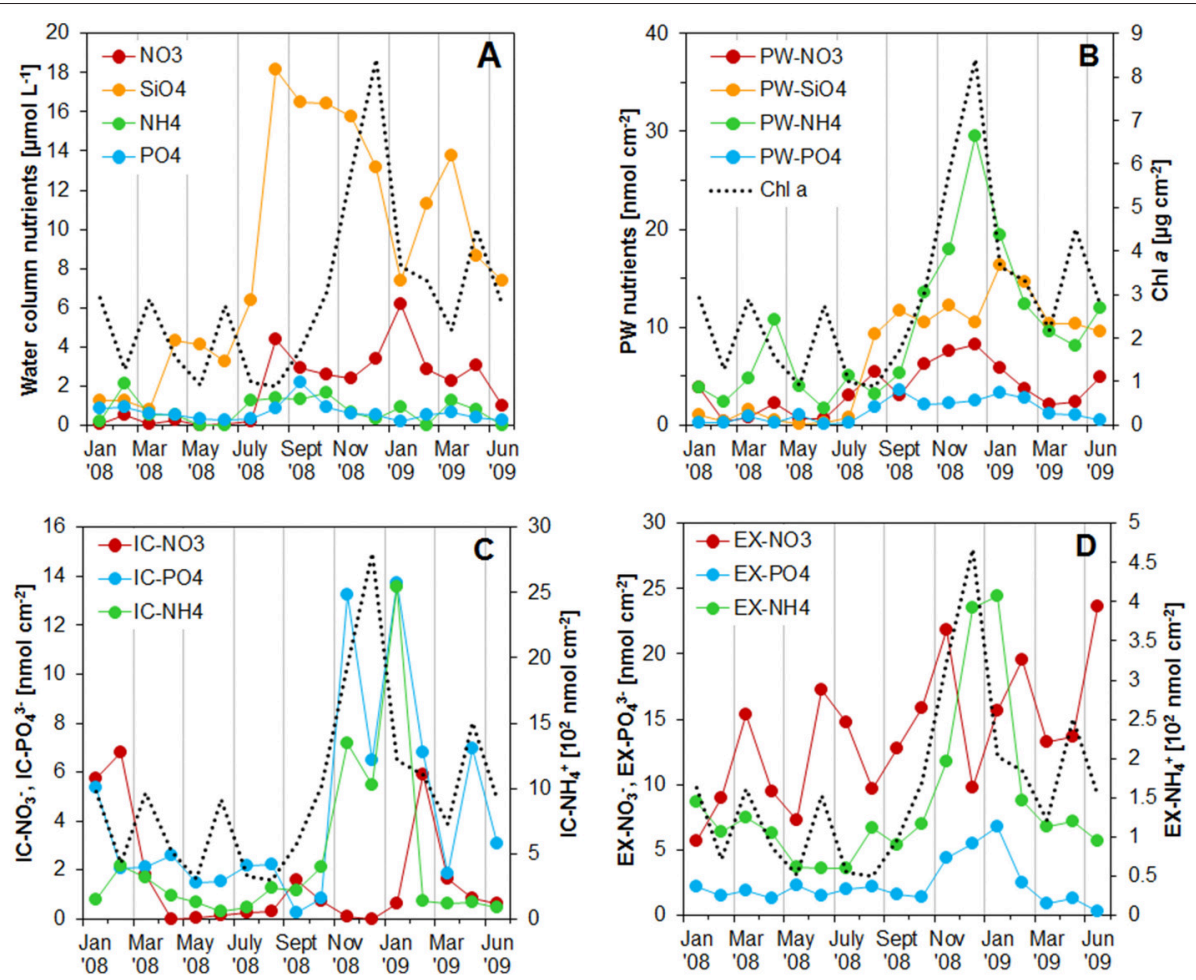

FIGURE 3 | (A) Concentration of nutrients in the water column at the sampling station on Trocadero Island, Bay of Cádiz, from January 2008 to June 2009. (B-D) Integrated nutrient pools in the first $4 \mathrm{~mm}$ of the sediment: (B) porewater, (C) intracellular, and (D) exchangeable pools. Integrated Chlorophyll a content was also drawn in all the graphs for comparison. Notice the different scale $\left(10^{2} \mathrm{nmol} \mathrm{cm}{ }^{-3}\right)$ for intracellular and exchangeable ammonium pools in $\mathbf{C}$ and $\mathbf{D}$.

(Figure 4). The $\mathrm{EX}-\mathrm{NH}_{4}^{+}$fraction was always higher that $\mathrm{PW}$ $\mathrm{NH}_{4}^{+}$at all depths, but equal or lower than IC- $\mathrm{NH}_{4}^{+}$, comprising $37 \pm 13 \%$ of the total. $\mathrm{EX}^{-\mathrm{NH}_{4}^{+}}$fraction showed its lowest contribution in autumn. Surprisingly, $\mathrm{EX}_{-} \mathrm{NO}_{3}^{-}$was the most abundant nitrate fraction in the sediment $(69 \pm 17 \%)$, with its relative contribution being highest from March to June in both years.

\section{Photosynthetic Pigments, Organic Matter, and Net Production}

Chlorophyll (Chl) content varied significantly over time and with depth in the sediment, especially in the upper few millimeters of the sediment (Figure 5). During the late autumn and winter months, chlorophylls content was highest at the sediment surface $\left(12.0 \pm 2.9\right.$ and $6.6 \pm 0.8 \mu \mathrm{g} \mathrm{cm}^{-3}$ for Chl $a$ and Chl $c$, respectively); chlorophylls decreased exponentially with depth to relatively low concentrations remaining constant below 4-5 mm $\left(3.2 \pm 0.4\right.$ and $5.1 \pm 0.4 \mu \mathrm{g} \mathrm{cm}^{-3}$ at deeper layers for Chl $a$ and Chl $c$, respectively; Figure 6).

Concentrations at the sediment surface $(<4 \mathrm{~mm})$ showed a clear seasonal pattern (Figures 5, 6). Maximum concentration for both Chl $a$ and $c$ was found during late autumn (NovemberDecember 2008), whereas minimum values were measured during spring and summer (April-August 2008 and May-June 2009). A secondary Chl $a$ maximum was detected in March 2009 without, however, a parallel increase in Chl $c$ (Figure 6).
Organic matter (OM) content showed similar variations over time and with depth to those of photosynthetic pigments (Figures 5, 6). Highest OM content was found in the first few millimeters of sediment during the end of autumn-beginning of winter (November to February; Figure 5). Maximum integrated values were observed in January 2008 and 2009 (45.6 and $44.5 \mathrm{mg} \mathrm{cm}^{-2}$, respectively; Figure 6), whereas minimum values during in June 2008 and 2009 (31 and $30.6 \mathrm{mg} \mathrm{cm}^{-2}$, respectively). On average, $\mathrm{OM}$ content at the surface was $91.5 \pm 3.3 \mathrm{mg} \mathrm{g}^{-1}$, decreasing progressively to $80 \pm 2.1 \mathrm{mg}$ $\mathrm{g}^{-1}$ at $10 \mathrm{~mm}$ depth (Figure 6). However, the temporal pattern of $\mathrm{OM}$ presented certain discrepancies compared to that of photosynthetic pigments; in January 2009 and for the period from July to August 2008, peaks in OM were not reflected in similar peaks in the photosynthetic pigments.

Sediment cores were always net autotrophic when illuminated at $800 \mu \mathrm{E} \mathrm{m} \mathrm{m}^{-2} \mathrm{~s}^{-1}$ in the lab, resulting in positive NDP rates during most of the sampling period (Figure 7). During late winter and spring, NDP rates were relatively low; lower than $10 \mathrm{mmol} \mathrm{O}_{2} \mathrm{~m}^{-2} \mathrm{~d}^{-1}$ and even negative on occasions. NDP increased during summer and autumn months, reaching maximum rates of $43-46 \mathrm{mmol} \mathrm{O}_{2} \mathrm{~m}^{-2} \mathrm{~d}^{-1}$ in July and November 2008. A secondary peak in NDP rates was observed again in February and March 2009 with values close to $20 \mathrm{mmol}$ $\mathrm{O}_{2} \mathrm{~m}^{-2} \mathrm{~d}^{-1}$. 


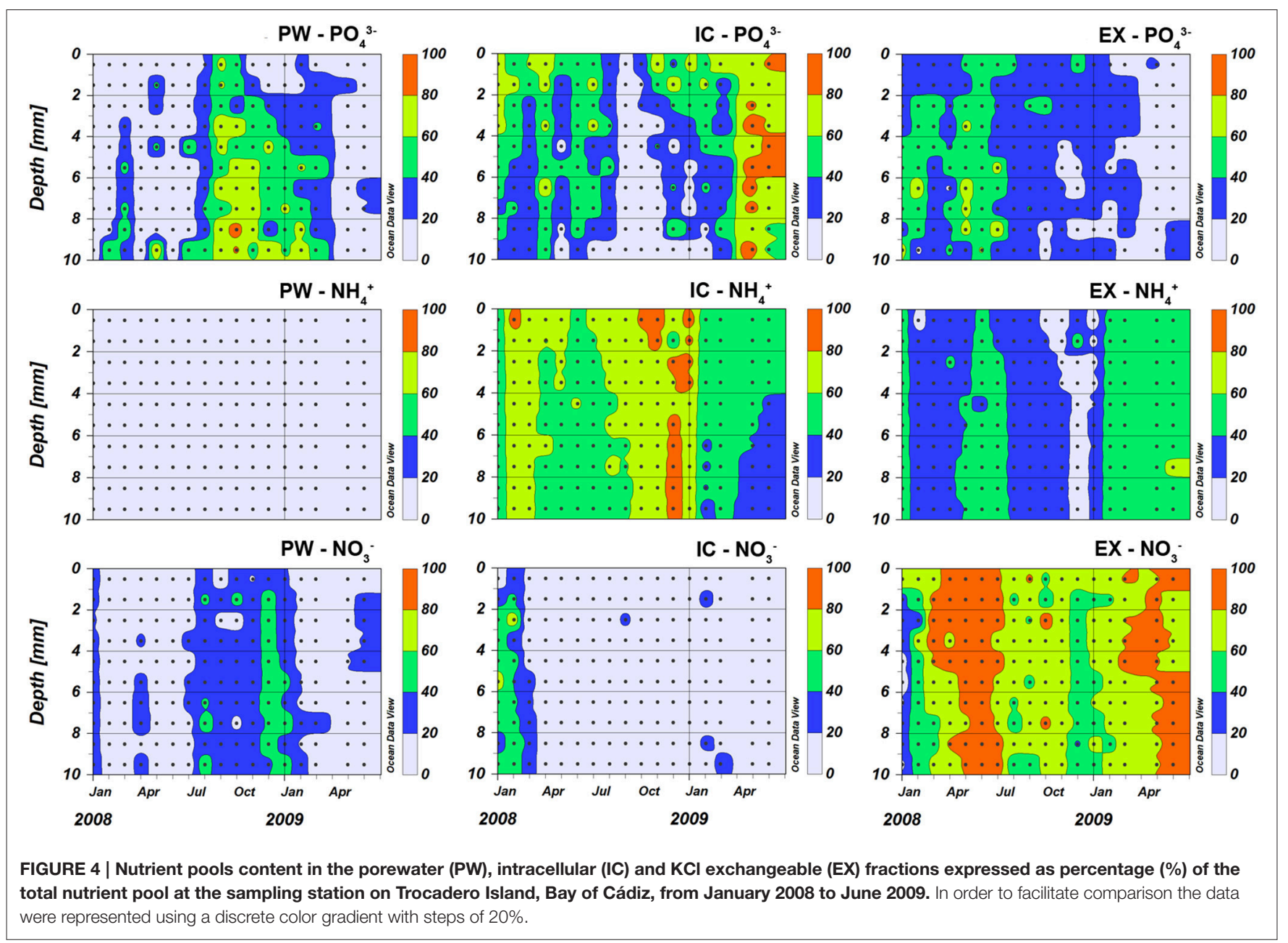

\section{Statistical Analysis of the Vertical and Seasonal Variability of Sediment Inorganic Nutrient Fractions}

Nutrients were positively correlated between each other only within the PW fraction (Figure 8). When looking across the different pools, all three ammonium sediment fractions strongly correlated with each other, as well as with both Chlorophylls a and c, and OM. Phosphate fractions also significantly correlated with both Chlorophylls and OM. However, correlations between the different Phosphate fractions varied; $\mathrm{PW}-\mathrm{PO}_{4}^{3-}$ was inversely correlated with $\mathrm{IC}-\mathrm{PO}_{4}^{3-}$, whereas no correlation was found between $\mathrm{PW}-\mathrm{PO}_{4}^{3-}$ and $\mathrm{EX}-\mathrm{PO}_{4}^{3-}$. Nitrate fractions were both positively ( $\mathrm{PW}-\mathrm{NO}_{3}^{-}$and $\mathrm{IC}-\mathrm{NO}_{3}^{-}$) and negatively (EX-NO$-\mathrm{NO}_{3}^{-}$) correlated with $\mathrm{OM}$ content. Only $\mathrm{EX}^{-\mathrm{NO}_{3}^{-}}$fraction showed a significant correlation with $\mathrm{Chl} a$. Within the nitrate pools, the only significant relation was found the negative correlation between $\mathrm{PW}-\mathrm{NO}_{3}^{-}$and $\mathrm{IC}-\mathrm{NO}_{3}^{-}$.

In order to exclude the vertical variability, a second round of correlation analysis was performed between the sediment variables integrated in the top sediment layers $(0-4 \mathrm{~mm})$, where most of the changes were observed, and water column or rate variables (Figure 9). Silicate and phosphate in the water column were positively correlated with $\mathrm{Chl} c$ content in the surface sediment. Silicate was also the only nutrient that correlated with NDP. Water column silicate and nitrate correlated with $\mathrm{PW}-\mathrm{SiO}_{4}^{4-}$ and $\mathrm{PW}-\mathrm{NO}_{3}^{-}$, respectively, but no such relations could be observed for phosphate and ammonium. Rainfall showed a positive correlation with the nutrients with the lowest concentrations overall (phosphate and ammonium), but not with the most abundant ones (nitrate and silicate). Same as before, nutrients in the PW fraction correlated with each other and were all positively correlated with chlorophylls. Between fractions, all three ammonium pools showed positive correlations, but not phosphate and nitrate. An inverse correlation was found between $\mathrm{PW}-\mathrm{NO}_{3}^{-}$and $\mathrm{IC}-\mathrm{NO}_{3}^{-}$.

Chlorophylls content was correlated with the IC and EX fractions of ammonium and phosphate, whereas no relation was found with nitrate fractions. NDP showed an inverse correlation with $\mathrm{IC}-\mathrm{NO}_{3}^{-}$and $\mathrm{IC}-\mathrm{PO}_{4}^{3-}$ and a direct relationship with temperature and irradiance. All the other variables (namely nutrient fractions, pigments and organic matter content) were inversely correlated with air temperature and irradiance, with variable degrees of significance (Figure 9). 


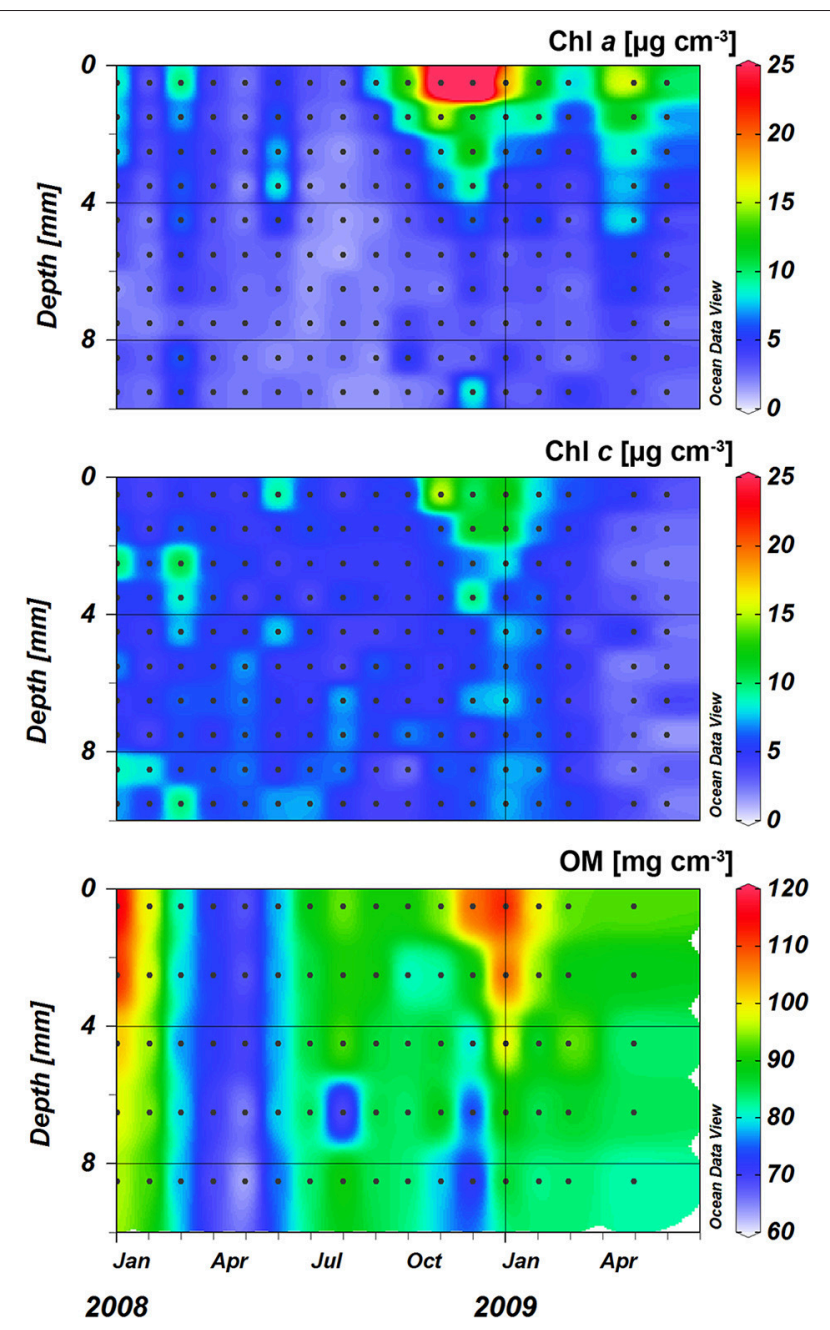

FIGURE 5 | Chlorophyll a (Chl a), chlorophyll c (Chl c), and organic matter (OM) profiles at the sampling station on Trocadero Island, Bay of Cádiz, from January 2008 to June 2009. Data are mean of 3 sediment plots.

\section{DISCUSSION}

\section{Microphytobenthos Seasonality and Inorganic Nutrients Dynamics in the Pore Water and Water Column}

Chl $a$ concentration, an estimate of MPB abundance (Macintyre et al., 1996), can vary over an annual cycle as a function of abiotic factors such as temperature, light, and nutrients concentration, or disturbance events such as grazing and resuspension (Thornton et al., 2002). The relative effect of these factors produces the differences observed in sediment chlorophyll standing stocks between sampling sites. In the Bay of Cádiz, Chl $a$ showed large variations at the sediment surface over the sampling period. Values ranged from 1.7 to $36 \mu \mathrm{g} \mathrm{cm}{ }^{-3}$, being similar to those measured previously in the area (García-Robledo et al., 2010; Bohórquez et al., 2013) or in other temperate regions (Brotas and Plante-Cuny, 1998; Wolfstein et al., 2000; Du et al., 2009).
The seasonal pattern of MPB abundance observed in the Bay of Cádiz, with minimum chlorophyll values in summer and highest in early winter is typical of similar latitude sediments (Brito et al., 2013), and is only occasionally found at higher latitude systems (Stief et al., 2013). In the latter, typically, an annual uni-modal maximum occurs in summer, which is usually attributed to the higher light availability and temperature during that period (de Jong and de Jonge, 1995; Wolfstein et al., 2000; Kang et al., 2006; Spilmont et al., 2006). In the Bay of Cádiz, however, pigment concentrations were negatively correlated with both irradiance and temperature (Figure 9). Thermo-inhibition and excessive sediment desiccation during emersion in summer (Blanchard et al., 1997; Morris and Kromkamp, 2003) and photoinhibition (Blanchard et al., 2004; Serôdio et al., 2008) probably affect MPB negatively. In addition, the higher grazer activity usually observed during spring and summer might also reduce $\mathrm{MPB}$ abundance during those periods (Gall and Blanchard, 1995; Pinckney et al., 2003).

In addition to the above, MPB abundance also depends on the nutrient supply from the water column. Higher Chl $a$ concentrations are often found during winter months, when the runoff and leaching caused by rainfall is higher (Underwood and Paterson, 1993; Du et al., 2009; Stief et al., 2013). Water column nutrients in the Bay of Cádiz followed this seasonal pattern with higher values in autumn and winter (Figure 3), when precipitation is also highest in the area (Figure S1). Notwithstanding, despite of the high urbanization of the area, annual mean water column nutrient concentrations are low (present dataset; Morris et al., 2009; Papaspyrou et al., 2013), and could thus control MPB abundance (Welker et al., 2002; Stief et al., 2013). Although, no correlation was found between water column nutrient concentrations and annual pigments maxima (Figure 9), NDP was positively correlated with water column silicate, suggesting that this nutrient can be limiting for MPB in the Cadiz Bay. On the other hand, the mismatch observed in the temporal evolution of pigments and NDP, in particular the high NDP but low $\mathrm{Chl} a$ and $\mathrm{Chl} c$ values during the summer months, could be partially due to changes in the Chl $a$ to carbon ratio, resulting in higher biomass with lower Chlorophyll (de Jonge, 1980) or a higher grazing activity during summer as mentioned above, which may limit the abundance of highly active MPB.

Porewater nutrients can be a significant nutrient source for MPB which in turn can largely control their availability in the porewater (Rysgaard et al., 1995; Risgaard-Petersen, 2003). As a result, positive, negative, or a lack of correlation have been found between Chl $a$ and porewater nutrients (Du et al., 2009 and references therein). In Cadiz Bay, we found significant positive correlations between seasonal changes in $\mathrm{Chl} a$ and $\mathrm{Chl} c$ and $\mathrm{PW}$ nutrients, but not with water column nutrients (Figure 9). This fact supports the importance of pore water nutrients for MPB dynamics. Silicate in particular seems act as a limiting nutrient in the Bay of Cadiz; in addition to the aforementioned relation between NDP and water column silicate, sediment pigments content correlated with $\mathrm{PW}-\mathrm{SiO}_{4}^{4-}$. Given that the intertidal MPB community in the Bay of Cadiz is usually dominated by diatoms (García-Robledo et al., 2012), silicate seems to control 

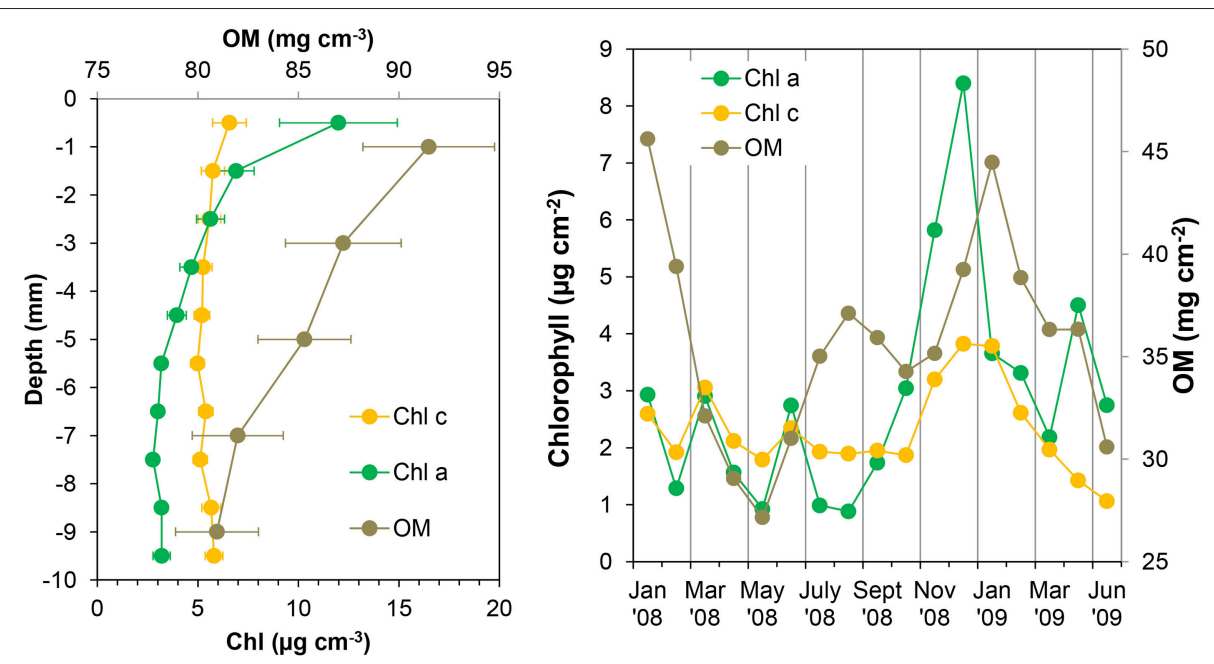

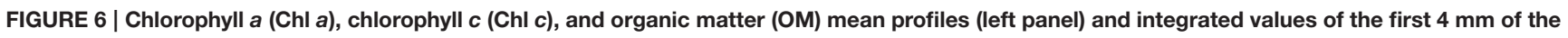
sediment (right panel) at the sampling station on Trocadero Island, Bay of Cádiz, from January 2008 to June 2009. Data are mean \pm SD.

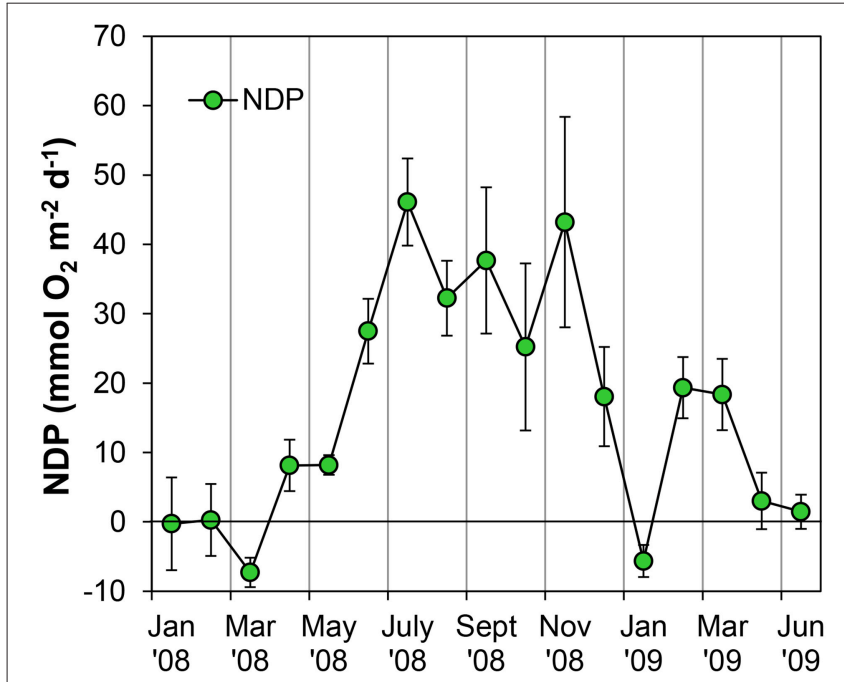

FIGURE 7 | Evolution of potential Net Daily Production (NDP) metabolism measured as Oxygen flux at the sediment-water interface using oxygen microsensors at the sampling station on Trocadero Island, Bay of Cádiz, from January 2008 to June 2009. Data are mean of 4-6 sediment cores \pm SD.

to a large extent the MPB dynamics in the area due to its role for diatom growth.

\section{Intracellular Nutrients in the Intertidal Sediments of Cadiz Bay}

Intracellular nutrients in the intertidal sediments of the Cadiz Bay clearly accumulated during certain periods of time (Figures 1, 3). Seasonal variations of IC nutrients have been studied previously only in two coastal environments: in Cadiz Bay, where winter and summer IC nutrient concentrations correlated with MPB abundance (García-Robledo et al., 2010), and in the Wadden

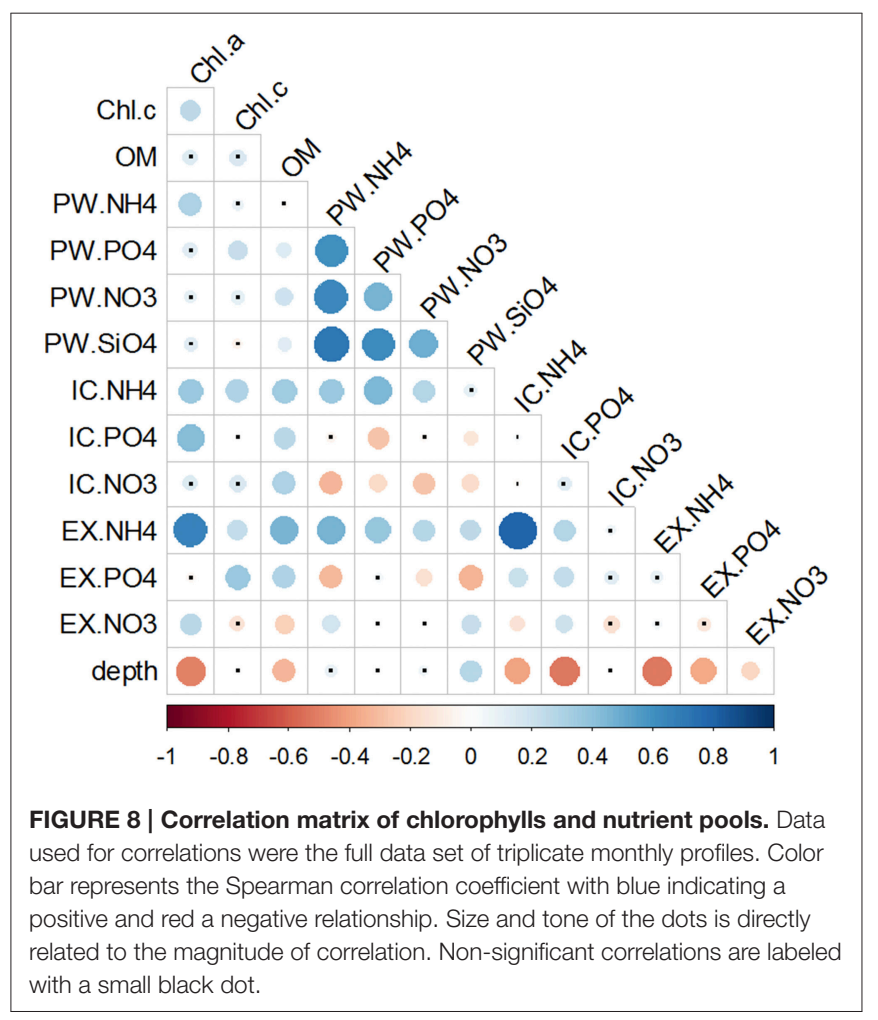

Sea, where the variation of the $\mathrm{IC}^{-} \mathrm{NO}_{3}^{-}$pool in intertidal sediments along 1 year was related to the water column nitrate concentration and the benthic diatoms abundance (Stief et al., 2013). In the present study, the highest accumulations of IC$\mathrm{NH}_{4}^{+}$and $\mathrm{IC}-\mathrm{PO}_{4}^{3-}$ were found in the first few millimeters of the sediment during autumn 2008, when maximum Chl $a$ and $\mathrm{Chl} c$ values were also measured, suggesting a direct relation between IC pools and MPB abundance. In contrast, the $\mathrm{IC}^{-\mathrm{NO}_{3}^{-}}$pool was more variable and no clear relationship with $\mathrm{Chl} a$, such as the 


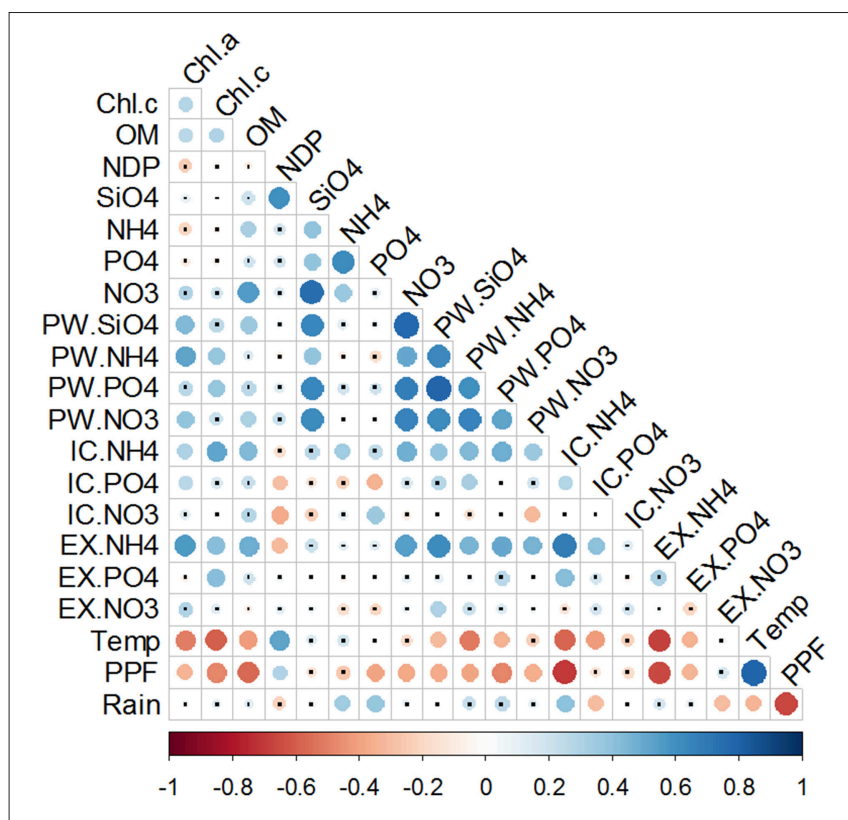

FIGURE 9 | Correlation matrix of the integrated variables in the first 4 $\mathrm{mm}$ of the sediment, water column nutrient concentrations, meteorological data and Net metabolism. Chl.a and Chl.c represent the integrated pigment values in the first $4 \mathrm{~mm}$ of the sediment. $\mathrm{SiO}_{4}^{4-}, \mathrm{NH}_{4}^{+}$, $\mathrm{PO}_{4}^{3-}$, and $\mathrm{NO}_{3}^{-}$represent the nutrient concentration in the water column. PW, IC, and EX stand for porewater, intracellular, and exchangeable pools, respectively. Temperature (Temp), photosynthetic photon flux (PPF), and Rain were obtained from a meteorological station localized in the outer part of the Bay. Potential Net Daily Production (NDP) was measured as the oxygen fluxes at the sediment-water interface. Color bar represents the Spearman correlation coefficient with blue data for positive and red for negative relationship. Size and tone of the dots is directly related to the magnitude of the correlation. Non-significant correlations are labeled with a small black dot.

one described by Stief et al. (2013) for the Wadden Sea, was found here, suggesting a more complex regulation of this intracellular nutrient pool in the Bay of Cadiz.

The intracellular accumulation of any inorganic nutrient is the result of the balance between nutrient uptake, strongly dependent on the external supply, and its assimilation into organic compounds. In addition, the $\mathrm{IC}-\mathrm{NO}_{3}^{-}$pool can be used by diatoms for dissimilatory nitrate reduction (Kamp et al., 2011), a major pathway for nitrate removal in some areas (Stief et al., 2013; Marchant et al., 2014). The IC- $\mathrm{NO}_{3}^{-}$content of the sediment in the Wadden Sea $\left(0-20 \mathrm{nmol} \mathrm{cm}^{-3}\right.$, with a peak

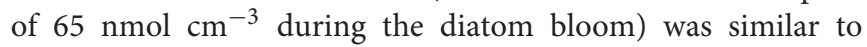
the one we measured in Cadiz Bay. However, the low nutrient concentrations in the water column and the succession of IC$\mathrm{NO}_{3}^{-}, \mathrm{NDP}$, and $\mathrm{Chl} a$ peaks suggest that the intracellular nutrient pool was mainly used for assimilation and growth of MPB community rather than dissimilatory processes. Nevertheless, rates of dissimilatory reduction of nitrate to ammonium have not been quantified for our area. This process could be important for $\mathrm{N}$ cycling in Cadiz Bay sediments and should be taken into account in future investigations in the area.

In addition to diatoms, other microorganisms such as Thioploca, Beggiatoa, and foraminifera can accumulate millimolar concentrations of nitrate in intracellular vacuoles (Fossing et al., 1995; Sayama et al., 2005; Piña-Ochoa et al., 2010; Kamp et al., 2015). Although these microorganisms could contribute significantly to or even dominate the $\mathrm{IC}^{-\mathrm{NO}_{3}^{-}}$pool in some surface sediments, we believe that this is not the case in the inner Cadiz Bay. Thioploca and Beggiatoa are usually found in organic-rich sulfidic sediments but these conditions are not common in the iron-rich intertidal sediments of Cadiz Bay (Jiménez-Arias et al., 2016). Of the foraminifera groups found in the sediments of Cadiz Bay some are known to accumulate nitrate and perform denitrification; however, their abundance was very low and no relationship with water column or porewater nitrate was established (Papaspyrou et al., 2013). Therefore, the IC- $\mathrm{NO}_{3}^{-}$pool in the intertidal sediments of the inner Cadiz Bay is most likely related to benthic microalgae.

Both $\mathrm{IC}-\mathrm{NH}_{4}^{+}$and $\mathrm{IC}-\mathrm{PO}_{4}^{3-}$ showed a positive correlation with $\mathrm{Chl} a$ and $\mathrm{Chl} c$, both on the vertical and the temporal scale, suggesting that microbenthic community, in addition to nitrate, accumulate intracellularly ammonium and phosphate (Figures $\mathbf{8}$, 9). Accumulation of $\mathrm{IC}-\mathrm{NH}_{4}^{+}$has been previously described for planktonic diatoms (Dortch, 1982; Thoresen et al., 1982); this accumulated ammonium is also detected in the sediment after the sedimentation of a phytoplanktonic bloom (Lomstein et al., 1990). In Cadiz Bay, high $\mathrm{IC}-\mathrm{NH}_{4}^{+}$concentrations were measured with seasonal differences between summer and winter being clearly related to MPB abundance (García-Robledo et al., 2010). Similarly to ammonium, accumulation of phosphate has been shown in planktonic diatoms (Miyata et al., 1986), cyanobacteria (Mateo et al., 2006), and more recently in benthic diatoms (García-Robledo et al., 2010; Yamaguchi et al., 2015).

MPB might accumulate ammonium and phosphate to use them for assimilation and growth. In order to evaluate the relevance of these pools for the growth of MPB, the minimal algal nutrient demand was estimated using the Chl $a$ increase during autumn 2008. Chl $a$ increased from $1.4 \mu \mathrm{g} \mathrm{cm}^{-2}$ in August 2008 to $15.9 \mu \mathrm{g} \mathrm{cm}^{-2}$ in December 2008. Considering $\mathrm{N}: \mathrm{Chl}$ $a$ and P:Chl $a$ ratios of 5.58 and 1.15, respectively -measured for the benthic diatom Navicula sp. (Montani et al., 2003)-a minimum of $80.9 \mathrm{nmol} \mathrm{N} \mathrm{cm}{ }^{-2}$ and $16.7 \mathrm{nmol} \mathrm{P} \mathrm{cm}{ }^{-2}$ would be required to produce the measured Chl $a$ peak. Similarly, the Chl $a$ peak measured in March 2009, a net increase of $7.3 \mu \mathrm{g} \mathrm{Chl}$ $a \mathrm{~cm}^{-2}$ from January, corresponded to a demand of $40.9 \mathrm{nmol}$ $\mathrm{N} \mathrm{cm}^{-2}$ and $8.4 \mathrm{nmol} \mathrm{P} \mathrm{cm}^{-2}$. Those values are likely minimum estimations as no losses due to grazing, resuspension or mortality are considered.

For phosphorus, the requirement estimates obtained were quite similar to the $13 \mathrm{nmol}$ IC- $\mathrm{PO}_{4}^{3-} \mathrm{cm}^{-2}$ measured in November 2008, just before the Chl a peak in December 2008, and the 7 nmol IC- $\mathrm{PO}_{4}^{3-} \mathrm{cm}^{-2}$ measured in February 2009, just before the peak in March 2009. Thus, it seems plausible that MPB accumulated phosphate intracellularly to be used for net growth, independently of the external nutrient supply. Although our calculations on phosphorus demand agree well with the $\mathrm{IC}-\mathrm{PO}_{4}^{3-}$ pool, MPB can also accumulate large quantities of phosphorus as polyphosphate which could have been broken down to some extent by the extraction procedure and measured as phosphate. In addition, other organisms such as 
bacteria could have contributed to the phosphate (Aller, 1994) or polyphosphates measured in the IC- $\mathrm{PO}_{4}^{3-}$ pool, the latter being a relevant phosphorus pool in freshwater sediments (Gächter et al., 1988).

Contrary to phosphorus, the IC- $\mathrm{NH}_{4}^{+}$pool exceeded by far the estimated requirements for growth, being as high as $1400 \mathrm{nmol}$ $\mathrm{cm}^{-2}$ during November 2008. Therefore, despite the significant correlation between IC- $\mathrm{NH}_{4}+$ and photosynthetic pigments (Figures 8,9), probably other ammonium pools, additional to the MPB intracellular one, were contributing to the large IC- $\mathrm{NH}_{4}^{+}$ measured in the sediments of Cadiz Bay. Bacterial abundance is generally well coupled to $\mathrm{Chl} a$ in sediments (Middelburg et al., 2000), therefore it is reasonable to attribute to bacteria a large fraction of the IC- $\mathrm{NH}_{4}^{+}$pool. Aller (1994) found concentrations of lysable ammonium as high as $7 \mu \mathrm{mol} \mathrm{NH}_{4}^{+} \mathrm{g}^{-1}$ in aphotic sediments and a direct correlation with bacterial abundance. Considering a sediment density of $2.5 \mathrm{~g} \mathrm{~cm}^{-3}$, this IC- $\mathrm{NH}_{4}^{+}$ content corresponds to $2800 \mathrm{nmol} \mathrm{cm}{ }^{-3}$. The magnitude of this content is similar to the one measured in the present study during the Chl a peak ocurring in December 2008. In addition, other sources of nutrients, such as micro- and meiofauna, as well as different types of phytodetritus, could co-vary with MPB and may also have contributed to the IC- $\mathrm{NH}_{4}^{+}$pool (Lomstein et al., 1990; Corzo et al., 2009). In the future, an effort should be made to distinguish the sources contributing to the measured IC pools, if we wish to understand the observed differences in the temporal and vertical distribution of the intracellular pools among sites and establish valid links between IC pools and MPB primary production and biomass.

\section{Exchangeable Nutrients and the Relative Importance of Each Nutrient Pool}

Exchangeable ammonium and phosphate are considered important nutrient reservoirs in marine sediments (Lomstein et al., 1990; Laima, 1992; Aller, 1994; Yamaguchi et al., 2015). Accordingly, in Cadiz Bay, EX-NH$H_{4}^{+}$and $\mathrm{EX}-\mathrm{PO}_{4}^{3-}$ content was on average 15 and 10 times higher, respectively, than the corresponding porewater one, despite the $\mathrm{EX}-\mathrm{NH}_{4}^{+}$and $-\mathrm{PO}_{4}^{3-}$ variations throughout the year and with depth in the sediment (Figures 3, 4). Concentrations were generally higher in the upper part of the sediment, decreasing with depth, and higher during late autumn months, when chlorophylls and OM were also highest. EX nutrients concentration measured in Cadiz Bay sediments are similar to those in other muddy sediments from coastal areas, where a large temporal and spatial variability was also reported (Laima, 1992; Van Raaphorst and Malschaert, 1996). For example, Laima (1992) found higher $\mathrm{EX}^{-\mathrm{NH}_{4}^{+}}$ following the phytoplankton sedimentation in Aarhus Bay (Denmark) with values up to $1400 \mathrm{nmol} \mathrm{cm}{ }^{-3}$ at the sediment surface, similar to the ones measured here. In the Mondego estuary (Portugal), integrated $\mathrm{EX}-\mathrm{PO}_{4}^{3-}$ values varied from 40 to $1380 \mathrm{mmol} \mathrm{m}^{-2}$ (Coelho et al., 2004), corresponding to $0.1-2.8$ $\mathrm{nmol} \mathrm{cm}{ }^{-2}$ (assuming homogeneous distribution and rescaling to $4 \mathrm{~mm}$ of sediment), similar to the integrated values measured here. Overall, the EX-PO ${ }_{4}^{3-}$ in Cadiz Bay followed the same evolution than the $\mathrm{EX}_{-} \mathrm{NH}_{4}^{+}$and suggests a common regulation.
Among other variables, loosely adsorbed ions concentration depends on porewater concentration, salinity, availability of binding sites, and temperature (Laima, 1992; Van Raaphorst and Malschaert, 1996; Coelho et al., 2004). Neither changes in granulometry, and as consequence in the amount of clay particles in the sediment (and available sorption sites), nor in salinity occur in Cadiz Bay during the course of a year, since no rivers flow into the bay. Organic matter, on the other hand, showed a clear seasonal pattern and was positively correlated with both EX$\mathrm{NH}_{4}^{+}$and $\mathrm{EX}-\mathrm{PO}_{4}^{3-}$ (Figures 8, 9). Sediment organic matter can control exchangeable pools in several ways. First, OM provides additional sorption sites for cations and can be the main source of binding sites for ammonium (Van Raaphorst and Malschaert, 1996). Second, OM acts as a source of nutrients during the remineralization process. Finally, organic ions can compete with inorganic anions for $\mathrm{Fe}$ and $\mathrm{Al}$ oxides adsorption sites, in the same way as it has been described for soils (Johnson and Todd, 1983; Hue, 1991; Gu et al., 1995).

Binding of nitrate to sediments is theoretically possible (Wang et al., 1987) and has been described both in soils (Katou et al., 1996; Matson et al., 1999) and in marine sediments already a few decades ago (Garber, 1984); however, the exchangeable nitrate fraction has not been investigated in detail. In marine environments, competition with $\mathrm{Cl}^{-}$and other anions reduces the availability of free sorption sites, leading to the misconception than an absorbed nitrate pool cannot exist. However, in the few cases where the $\mathrm{EX}-\mathrm{NO}_{3}^{-}$pool has been quantified, it has been found to be significant (Garber, 1984; Lomstein et al., 1990; Papaspyrou et al., 2014). Lomstein et al. (1990) found high $\mathrm{EX}-\mathrm{NO}_{3}^{-}$concentrations at the sediment surface of Aarhus Bay (up to $100 \mathrm{nmol} \mathrm{cm}{ }^{-3}$ ) and a quick decrease with depth. In the sediments of the hyper-nutrified Colne estuary (UK), high EX-NO $\mathrm{NO}_{3}^{-}$content was found several centimeters down in the sediment, with values usually above $10 \mathrm{nmol} \mathrm{g} \mathrm{ww}^{-1}$; although, no distinction was made between IC and EX pools (Papaspyrou et al., 2014). In both studies, the $\mathrm{EX}^{-\mathrm{NO}_{3}^{-}}$pool at the sediment surface was shown to be several times higher than $\mathrm{PW}-\mathrm{NO}_{3}^{-}$. In like manner, the $\mathrm{EX}-\mathrm{NO}_{3}^{-}$pool in Cadiz Bay was on average seven times higher than the porewater one, being up to 50 times higher at times. In fact, this $\mathrm{EX}^{-\mathrm{NO}_{3}^{-}}$pool was the main nitrate pool in Cadiz Bay sediments. The consolidated nature of the muddy sediment in our area suggests that the source is probably not nitrate introduced from the water column by advection, given also the generally low water column nitrate concentration. For the surface sediment, where oxygen penetrates (Papaspyrou et al., 2013), a potential source of nitrate could be bacterial nitrification, whereas for deeper layers, coupled nitrification-denitrification stimulated by the bioirrigation activities of micro- and meiofauna could be also possible (Bonaglia et al., 2014). However, the source of the $\mathrm{EX}-\mathrm{NO}_{3}^{-}$at depth remains to be determined.

The $\mathrm{EX}-\mathrm{NO}_{3}^{-}$fraction showed a larger variability with several peaks throughout the sampling period, compared to $\mathrm{EX}-\mathrm{NH}_{4}^{+}$ and $\mathrm{EX}-\mathrm{PO}_{4}^{3-}$. In addition, contrary to the other two nutrients, $\mathrm{EX}-\mathrm{NO}_{3}^{-}$was inversely correlated to the vertical distribution of $\mathrm{OM}$ content in the sediment and seemed to be more abundant after the $\mathrm{Chl}$ maximum values. These facts suggest that that $\mathrm{EX}-\mathrm{NO}_{3}^{-}$is more dynamic than $\mathrm{EX}-\mathrm{NH}_{4}^{+}$and $\mathrm{EX}-\mathrm{PO}_{4}^{3-}$ with 
additional factors controlling this pool. Although, an increase in organic matter following the Chl $a$ peak would provide more sorption sites for ammonium, the contrary would be true for nitrate due to the competition with organic ions (Schlesinger and Bernhardt, 2013). In addition, the high nitrogen demand by the MPB community could also result in a decrease of the EX$\mathrm{NO}_{3}^{-}$pool. Regardless of the mechanisms in action, the existence and variability of the EX-NO${ }_{3}^{-}$pool is not only relevant for the dynamics of the MPB. As suggested by Papaspyrou et al. (2014), the $\mathrm{EX}^{-\mathrm{NO}_{3}^{-}}$pool could be used by other components of the microbial community and may be supporting dissimilatory nitrate reduction processes at sediment depths where $\mathrm{PW}-\mathrm{NO}_{3}^{-}$ has been fully consumed. In the Bay of Cadiz, this pool seemed to be the most abundant and peaked when MPB abundance decreased. It is evident that further investigations about the dynamics of $\mathrm{EX}-\mathrm{NO}_{3}^{-}$and its role for nitrogen cycling are needed. The high concentrations usually found compared with the PW one and the apparent fast response to environmental factors suggest that this fraction is an important nitrate pool in marine sediments that potentially should be considered in biogeochemical and microbial ecology studies of sediment nitrogen cycling.

\section{CONCLUSIONS}

The simultaneous study of the three nutrient pools, PW, IC, and EX, in the upper $\mathrm{cm}$ of an intertidal sediment in Cadiz Bay over the course of a year showed that all three pools are highly dynamic and that their content is correlated with the distribution of microphytobenthos (MPB). Although, no data exist at present on the internal cycling of the different pools, our data suggest that IC and EX pools represent the major fraction of sediment total nutrient pools and that these could control to a large extent the dynamics of MPB in intertidal sediments. Refining various methodological aspects in order to define better the origins of each pool is necessary (e.g., distinguishing between microalgae and bacteria contributions), in order to understand the links not only between IC and EX pools and MPB primary production and biomass, but also the degree of exchange between the pools themselves. Finally, one of the most abundant pools observed

\section{REFERENCES}

Aller, R. C. (1994). Bioturbation and remineralization of sedimentary organic matter: effects of redox oscillation. Chem. Geol. 114, 331-345. doi: 10.1016/0009-2541(94)90062-0

Blanchard, G. F., Guarini, J. M., Dang, C., and Richard, P. (2004). Characterizing and quantifying photoinhibition in intertidal microphytobenthos. J. Phycol. 40, 692-696. doi: 10.1111/j.1529-8817.2004.03063.x

Blanchard, G. F., Guarini, J.-M., Gros, P., and Richard, P. (1997). Seasonal effect on the relationship between the photosynthetic capacity of intertidal microphytobenthos and temperature. J. Phycol. 33, 723-728. doi: 10.1111/j.0022-3646.1997.00723.x

Bohórquez, J., Papaspyrou, S., Yúfera, M., Van Bergeijk, S. A., García-Robledo, E., Jiménez-Arias, J. L., et al. (2013). Effects of green macroalgal blooms on the meiofauna community structure in the Bay of Cádiz. Mar. Pollut. Bull. 70, 10-17. doi: 10.1016/j.marpolbul.2013.02.002 here, that of $\mathrm{EX}-\mathrm{NO}_{3}^{-}$, which is usually not considered, should be taken into account in future studies of sediment nitrogen cycling given its potential importance for various nitrogen processes. It is clear that we urgently need to expand our database from areas with different sediment characteristics and MPB cycle patterns to shed some more light on the sediment "black box"; most likely we will have to revise and redefine several aspects of benthic nutrient dynamics.

\section{AUTHOR CONTRIBUTIONS}

All the authors designed the study and carried out the samplings. EG and SP analyzed the samples and the data. All authors interpreted the data and wrote the manuscript.

\section{FUNDING}

The study was funded by projects, CTM2013-43857-R from the Spanish Ministry of Economy and Competitiveness and P11RNM-7199 from Consejería de Innovación, Ciencia y Empresa, Junta de Andalucía. JB was funded by a fellowship grant from the Ministry of Education and Science (BES- 2010-035711) and JJ by a University of Cádiz Plan Propio fellowship grant (2010-063). SP was funded by a JAE-Doc fellowship (Programa JAE, JAE-Doc109, Spanish National Research Council) and a Marie Curie ERG action (NITRICOS, 235005, European Union).

\section{ACKNOWLEDGMENTS}

Manolo Arjonilla, Instituto de Ciencias Marinas de Andalucia (CSIC), for the excellent technical assistance with the Technicon autoanalyser.

\section{SUPPLEMENTARY MATERIAL}

The Supplementary Material for this article can be found online at: http://journal.frontiersin.org/article/10.3389/fmicb. 2016.00761

Bonaglia, S., Nascimento, F. J. A., Bartoli, M., Klawonn, I., and Brüchert, V. (2014). Meiofauna increases bacterial denitrification in marine sediments. Nat. Commun. 5:5133. doi: 10.1038/ncomms6133

Brito, A. C., Benyoucef, I., Jesus, B., Brotas, V., Gernez, P., Mendes, C. R., et al. (2013). Seasonality of microphytobenthos revealed by remotesensing in a South European estuary. Cont. Shelf Res. 66, 83-91. doi: 10.1016/j.csr.2013.07.004

Brotas, V., and Plante-Cuny, M. R. (1998). Spatial and temporal patterns of microphytobenthic taxa of estuarine tidal flats in the Tagus Estuary (Portugal) using pigment analysis by HPLC. Mar. Ecol. Prog. Ser. 171, 43-57. doi: 10.3354/meps 171043

Coelho, J. P., Flindt, M. R., Jensen, H. S., Lillebø, A. I., and Pardal, M. A. (2004). Phosphorus speciation and availability in intertidal sediments of a temperate estuary: relation to eutrophication and annual Pfluxes. Estuar. Coast. Shelf Sci. 61, 583-590. doi: 10.1016/j.ecss.2004. 07.001 
Corzo, A., Van Bergeijk, S. A., and García-Robledo, E. (2009). Effects of green macroalgal blooms on intertidal sediments: net metabolism and carbon and nitrogen contents. Mar. Ecol. Prog. Ser. 380, 81-93. doi: 10.3354/meps07923

de Jong, D., and de Jonge, V. N. (1995). Dynamics and distribution of microphytobenthic chlorophyll-a in the Western Scheldt estuary (SW Netherlands). Hydrobiologia 311, 21-30. doi: 10.1007/BF00008568

de Jonge, V. N. (1980). Fluctuations in the organic-carbon to chlorophyll-alpha ratios for estuarine benthic diatom populations. Mar. Ecol. Progress Ser. 2, 345-353. doi: 10.3354/meps002345

Dortch, Q. (1982). Effect of growth conditions on accumulation of internal nitrate, ammonium, amino acids, and protein in three marine diatoms. J. Exp. Mar. Biol. Ecol. 61, 243-264. doi: 10.1016/0022-0981(82)90072-7

Du, G., Son, M., Yun, M., An, S., and Chung, I. K. (2009). Microphytobenthic biomass and species composition in intertidal flats of the Nakdong River estuary, Korea. Estuar. Coast. Shelf Sci. 82, 663-672. doi: 10.1016/j.ecss.2009.03.004

Fossing, H., Gallardo, V. A., Jorgensen, B. B., Huttel, M., Nielsen, L. P., Schulz, H., et al. (1995). Concentration and transport of nitrate by the matforming sulphur bacterium Thioploca. Nature 374, 713-715. doi: 10.1038/ $374713 \mathrm{a} 0$

Gächter, R., Meyer, J. S., and Mares, A. (1988). Contribution of bacteria to release and fixation of phosphorus in lake sediments. Limnol. Oceanogr. 33, 1542-1558. doi: 10.4319/lo.1988.33.6_part_2.1542

Gall, C.-L., and Blanchard, G. (1995). Monthly HPLC measurements of pigment concentration from an intertidal muddy sediment of Marennes-Oléron Bay, France. Mar. Ecol. Prog. Ser. 121, 171-179. doi: 10.3354/meps121171

Garber, J. H. (1984). 15N tracer study of the short-term fate of particulate organic nitrogen at the surface of coastal marine sediments. Mar. Ecol. Prog. Ser. 16, 89-104. doi: 10.3354/meps016089

García-Robledo, E., Corzo, A., Papaspyrou, S., Jimenez-Arias, J. L., and Villahermosa, D. (2010). Freeze-lysable inorganic nutrients in intertidal sediments: dependence on microphytobenthos abundance. Mar. Ecol. Prog. Ser. 403, 155-163. doi: 10.3354/meps08470

García-Robledo, E., Corzo, A., Papaspyrou, S., and Morris, E. P. (2012). Photosynthetic activity and community shifts of microphytobenthos covered by green macroalgae. Environ. Microbiol. Rep. 4, 316-325. doi: 10.1111/j.17582229.2012.00335.x

Grasshoff, K., Ehrhardt, M., and Kremling, K. (1983). Methods of Sea Water Analysis. New York, NY: Verlag Chemie.

Gu, B., Schmitt, J., Chen, Z., Liang, L., and Mccarthy, J. F. (1995). Adsorption and desorption of different organic matter fractions on iron oxide. Geochim. Cosmochim. Acta 59, 219-229. doi: 10.1016/0016-7037(94)0 0282-Q

Heiri, O., Lotter, A. F., and Lemcke, G. (2001). Loss on ignition as a method for estimating organic matter and carbonate content in sediments: reproducibility and comparability of results. J. Paleolimnol. 25, 101-110. doi: 10.1023/A:1008119611481

Holmboe, N., and Kristensen, E. (2002). Ammonium adsorption in sediments of a tropical mangrove forest (Thailand) and a temperate Wadden Sea area (Denmark). Wetlands Ecol. Manage. 10, 453-460. doi: 10.1023/A:1021301918564

Hou, L. J., Liu, M., Xu, S. Y., Ou, D. N., Lu, J. J., Yu, J., et al. (2005). The effects of semi-lunar spring and neap tidal change on nutrients cycling in the intertidal sediments of the Yangtze estuary. Environ. Geol. 48, 255-264. doi: 10.1007/s00254-005-1304-4

Hue, N. (1991). Effects of organic acids/anions on $\mathrm{P}$ sorption and phytoavailability in soils with different mineralogies. Soil Sci. 152, 463-471. doi: 10.1097/00010694-199112000-00009

Jiménez-Arias, J. L., Mata, P., Corzo, A., Poulton, S., Maerz, C., Sanchez-Bellon, A., et al. (2016). A multiproxy study distinguishes environmental change from diagenetic alteration in the recent sedimentary record of the inner Cadiz Bay (SW Spain). Holocene. doi: 10.1177/0959683616640046. [Epub ahead of print].

Johnson, D. W., and Todd, D. (1983). Relationships among iron, aluminum, carbon, and sulfate in a variety of forest soils. Soil Sci. Soc. Am. J. 47, 792-800. doi: 10.2136/sssaj1983.03615995004700040035x

Kamp, A., De Beer, D., Nitsch, J. L., Lavik, G., and Stief, P. (2011). Diatoms respire nitrate to survive dark and anoxic conditions. Proc. Natl. Acad. Sci. U.S.A. 108, 5649-5654. doi: 10.1073/pnas. 1015744108
Kamp, A., Høgslund, S., Risgaard-Petersen, N., and Stief, P. (2015). Nitrate storage and dissimilatory nitrate reduction by eukaryotic microbes. Front. Microbiol. 6:1492. doi: 10.3389/fmicb.2015.01492

Kang, C.-K., Lee, Y.-W., Choy, E. J., Shin, J.-K., Seo, I.-S., and Hong, J.-S. (2006). Microphytobenthos seasonality determines growth and reproduction in intertidal bivalves. Mar. Ecol. Prog. Ser. 315, 113-127. doi: 10.3354/meps315113

Katou, H., Clothier, B. E., and Green, S. R. (1996). Anion transport involving competitive adsorption during transient water flow in an andisol. Soil Sci. Soc. Am. J. 60, 1368-1375. doi: 10.2136/sssaj1996.03615995006000050011x

Kühl, M., Glud, R. N., Ploug, H., and Ramsing, N. (1996). Microenviromental control of photosynthesis and photosynthesis-coupled respiration in an epilithic cyanobacterial biofilm. J. Phycol. 32, 799-812. doi: 10.1111/j.00223646.1996.00799.x

Laima, M. (1992). Extraction and seasonal variation of $\mathrm{NH}_{4}^{+}$pools in differert types of coastal marine sediments. Mar. Ecol. Prog. Ser. 82, 75-84. doi: 10.3354/meps082075

Lomstein, E., Jensen, M. H., and Sorensen, J. (1990). Intracellular $\mathrm{NH}_{4}^{+}$and $\mathrm{NO}_{3}^{-}$ pools associated with deposited phytoplankton in a marine sediment (Aarhus Bright, Denmark). Mar. Ecol. Prog. Ser. 61, 97-105. doi: 10.3354/meps061097

Macintyre, H. L., Geider, R. J., and Miller, D. C. (1996). Microphytobenthos: the ecological role of the "secret garden" of unvegetated, shallow-water marine habitats. I. Distribution, abundance and primary production. Estuaries 19, 186-201. doi: 10.2307/1352224

Mackin, J. E., and Aller, R. C. (1984). Ammonium adsorption in marine sediments. Limnol. Oceanogr. 29, 250-257. doi: 10.4319/lo.1984.29.2.0250

Marchant, H. K., Lavik, G., Holtappels, M., and Kuypers, M. M. M. (2014). The fate of nitrate in intertidal permeable sediments. PLOS ONE 9:e104517. doi: 10.1371/journal.pone.0104517

Mateo, P., Douterelo, I., Berrendero, E., and Perona, E. (2006). Physiological differences between two species of cyanobacteria in relation to phosphorous limitation. J. Phycol. 42, 61-66. doi: 10.1111/j.1529-8817.2006.00180.x

Matson, P. A., Mcdowell, W. H., Townsend, A. R., and Vitousek, P. M. (1999). The globalization of $\mathrm{N}$ deposition: ecosystem consequences in tropical environments. Biogeochemistry 46, 67-83. doi: 10.1007/BF01007574

Middelburg, J. J., Barranguet, C., Boschker, H. T. S., Herman, P. M. J., Moens, T., and Heip, C. H. P. (2000). The fate of intertidal microphytobenthos carbon: an in situ 13C-labeling study. Limnol. Oceanogr. 45, 1224-1234. doi: 10.4319/lo.2000.45.6.1224

Miyata, K., Hattori, A., and Ohtsuki, A. (1986). Variation of cellular phosphorus composition of Skeletonema costatum and Heterosigma akashiwo grown in chemostats. Mar. Biol. 93, 291-297. doi: 10.1007/BF00508266

Montani, S., Magni, P., and Abe, N. (2003). Seasonal and interannual patterns of intertidal microphytobenthos in combination with laboratory and areal production estimates. Mar. Ecol. Prog. Ser. 249, 79-91. doi: 10.3354/meps 249079

Morris, E. P., and Kromkamp, J. C. (2003). Influence of temperature on the relationship between oxygen-and fluorescence-based estimates of photosynthetic parameters in a marine benthic diatom (Cylindrotheca closterium). Eur. J. Phycol. 38, 133-142. doi: 10.1080/0967026031000085832

Morris, E. P., Peralta, G., Benavente, J., Freitas, R., Rodrigues, A. M., Quintino, V., et al. (2009). Caulerpa prolifera stable isotope ratios reveal anthropogenic nutrients within a tidal lagoon. Mar. Ecol. Prog. Ser. 390, 117-128. doi: 10.3354/meps08184

Papaspyrou, S., Diz, P., Garcia-Robledo, E., Corzo, A., and Jimenez-Arias, J. (2013). Benthic foraminiferal community changes and their relationship to environmental dynamics in intertidal muddy sediments (Bay of Cadiz, SW Spain). Mar. Ecol. Prog. Ser. 490, 121-135. doi: 10.3354/meps 10447

Papaspyrou, S., Smith, C. J., Dong, L. F., Whitby, C., Dumbrell, A. J., and Nedwell, D. B. (2014). Nitrate reduction functional genes and nitrate reduction potentials persist in deeper estuarine sediments. Why? PLOS ONE 9:e94111. doi: 10.1371/journal.pone.0094111

Piña-Ochoa, E., Høgslund, S., Geslin, E., Cedhagen, T., Revsbech, N. P., Nielsen, L. P., et al. (2010). Widespread occurrence of nitrate storage and denitrification among Foraminifera and Gromiida. Proc. Natl. Acad. Sci. U.S.A. 107, 1148-1153. doi: 10.1073/pnas.0908440107

Pinckney, J. L., Carman, K. R., Lumsden, S. E., and Hymel, S. N. (2003). Microalgalmeiofaunal trophic relationships in muddy intertidal estuarine sediments. Aquatic Microbial Ecol. 31, 99-108. doi: 10.3354/ame031099 
Revsbech, N. P., and Jorgensen, B. B. (1986). Microelectrodes: their use in microbial ecology. Adv. Microb. Ecol. 9, 293-352. doi: 10.1007/978-1-47570611-6_7

Risgaard-Petersen, N. (2003). Coupled nitrification-denitrification in autotrophic and heterotrophic estuarine sediments: on the influence of benthic microalgae. Limnol. Oceanogr. 48, 93-105. doi: 10.4319/lo.2003.48. 1.0093

Ritchie, R. J. (2008). Universal chlorophyll equations for estimating chlorophylls $\mathrm{a}, \mathrm{b}, \mathrm{c}$, and $\mathrm{d}$ and total chlorophylls in natural assemblages of photosynthetic organisms using acetone, methanol, or ethanol solvents. Photosynthetica 46, 115-126. doi: 10.1007/s11099-008-0019-7

Rocha, C. (1999). Rhythmic ammonium regeneration and fushing in intertidal sediments of the Sado estuary. Limnol. Oceanogr. 43, 823-831. doi: 10.4319/lo.1998.43.5.0823

Rocha, C., and Cabral, A. P. (1998). The influence of tidal action on porewater nitrate concentration and dynamics in intertidal sediments of the Sado estuary. Estuaries 21, 635-645. doi: 10.2307/1353301

Rysgaard, S., Christensen, P. B., and Nielsen, L. P. (1995). Seasonal variation in nitrification and denitrification in estuarine sediment colonized by benthic microalgae and bioturbating infauna. Mar. Ecol. Prog. Ser. 126, 111-121. doi: 10.3354/meps126111

Sayama, M., Risgaard-Petersen, N., Nielsen, L. P., Fossing, H., and Christensen, P. B. (2005). Impact of bacterial $\mathrm{NO}_{3}^{-}$transport on sediment biogeochemistry. Appl. Environ. Microbiol. 71, 7575-7577. doi: 10.1128/AEM.71.11.75757577.2005

Schlesinger, W. H., and Bernhardt, E. S. (eds.). (2013). "The Lithosphere, Chap. 4," in Biogeochemistry, 3rd Edn (Boston, MA: Academic Press), 93-133.

Serôdio, J., Vieira, S., and Cruz, S. (2008). Photosynthetic activity, photoprotection and photoinhibition in intertidal microphytobenthos as studied in situ using variable chlorophyll fluorescence. Cont. Shelf Res. 28, 1363-1375. doi: 10.1016/j.csr.2008.03.019

Spilmont, N., Davoult, D., and Migné, A. (2006). Benthic primary production during emersion: In situ measurements and potential primary production in the Seine Estuary (English Channel, France). Mar. Pollut. Bull. 53, 49-55. doi: 10.1016/j.marpolbul.2005.09.016

Stief, P., Kamp, A., and De Beer, D. (2013). Role of diatoms in the spatial-temporal distribution of intracellular nitrate in intertidal sediment. PLOS ONE 8:e73257. doi: 10.1371/journal.pone.0073257

Thompson, R. C., Tobin, M. L., Hawkins, S. J., and Norton, T. A. (1999). Problems in extraction and spectrophotometric determination of chlorophyll from epilithic microbial biofilms: towards a standard method. J. Mar. Biol. Assoc. U. K. 79, 551-558. doi: 10.1017/S0025315498000678
Thoresen, S. S., Dortch, Q., and Ahmed, S. I. (1982). Comparison of methods for extracting intracellular pools of inorganic nitrogen from marine phytoplankton. J. Plankton Res. 4, 695-704. doi: 10.1093/plankt/4.3.695

Thornton, D. C., Dong, L. F., Underwood, G. J., and Nedwell, D. B. (2002). Factors affecting microphytobenthic biomass, species composition and production in the Colne Estuary (UK). Aquatic Microbial Ecol. 27, 285-300. doi: $10.3354 / \mathrm{ame} 027285$

Underwood, G. J. C., and Paterson, D. M. (1993). Seasonal changes in diatom biomass, sediment stability and biogenic stabilization in the Severn Estuary. $J$. Mar. Biol. Assoc. U. K. 73, 871-887. doi: 10.1017/S0025315400034780

Van Raaphorst, W., and Malschaert, J. F. P. (1996). Ammonium adsorption in superficial North Sea sediments. Cont. Shelf Res. 16, 1415-1435. doi: 10.1016/0278-4343(95)00081-X

Wang, P. G., Ji, G. L., and Yu, T. R. (1987). Adsorption of chloride and nitrate by variable charge soils in relation to the electric charge of the soil. Zeitschrift für Pflanzenernährung und Bodenkunde 150, 17-23. doi: 10.1002/jpln.19871500105

Welker, C., Sdrigotti, E., Covelli, S., and Faganeli, J. (2002). Microphytobenthos in the gulf of trieste (Northern Adriatic Sea): relationship with labile sedimentary organic matter and nutrients. Estuar. Coast. Shelf Sci. 55, 259-273. doi: 10.1006/ecss.2001.0901

Wolfstein, K., Colijn, F., and Doerffer, R. (2000). Seasonal dynamics of microphytobenthos biomass and photosynthetic characteristics in the Northern German Wadden Sea, obtained by the photosynthetic light dispensation system. Estuar. Coast. Shelf Sci. 51, 651-662. doi: 10.1006/ecss.2000.0702

Yamaguchi, A., Umezawa, Y., Wada, M., and Sayama, M. (2015). Potential contribution of microalgal intracellular phosphorus to phosphorus distribution in tidal flat sediments during winter. Plankton Benthos Res 10, 1-10. doi: $10.3800 /$ pbr. 10.1

Conflict of Interest Statement: The authors declare that the research was conducted in the absence of any commercial or financial relationships that could be construed as a potential conflict of interest.

Copyright (c) 2016 Garcia-Robledo, Bohorquez, Corzo, Jimenez-Arias and Papaspyrou. This is an open-access article distributed under the terms of the Creative Commons Attribution License (CC BY). The use, distribution or reproduction in other forums is permitted, provided the original author(s) or licensor are credited and that the original publication in this journal is cited, in accordance with accepted academic practice. No use, distribution or reproduction is permitted which does not comply with these terms. 